Studia z Dziejów Średniowiecza nr 21, 2017

\author{
Weronika Konkol
}

(Gdańsk)

\title{
Gesty zniewagi w świetle polskich późnośredniowiecznych przekazów pisanych i ikonograficznych o Męce Pańskiej
}

Key words: insult, gesture, iconography, Passion of Jesus

Średniowiecze, słusznie nazwane przez Jacques'a Le Goffa epoka gestu $^{1}$, wytworzyło wiele form komunikacji pozawerbalnej. Obraz ówczesnej obyczajowości dopiero jest kompletny, gdy uzupełni się go o wszystkie treści, których nie wyrażano słowami. Wśród nich szczególnie interesujące wydają się zachowania obraźliwe, które jak dotąd nie doczekały się osobnego opracowania ${ }^{2}$. Niniejsze rozważania będą

1 J. Le Goff, Kultura średniowiecznej Europy, tłum. H. Szumańska-Grossowa, Warszawa 1994, s. 354; zob. też J.C. Schmidt; Gest w średniowiecznej Europie, tłum. H. Zaremska, Warszawa 2006; J.A., Burrow, Gestures And Looks In Medieval Narrative, Cambridge 2008.

2 Zwrócił na to ostatnio uwagę K. Kopania, zob. idem, Przedstawienia odrażajace w późnośredniowiecznym malarstwie z terenów dzisiejszej Polski-zarys problematyki [w:] Ars historiae - historia artis: prace ofiarowane profesorowi Andrzejowi Wyrobiszowi, red. E. Dubas-Urwanowicz, J. Maroszek, Białystok 2012, s. 63-65. Wzmianki o gestach zniewagi pojawiają się marginalnie, przy okazji innych rozważań, zob. np. E. Kizik, O źródtach i metodzie badań nad seksualnościa w Polce XIV-XVI. Odpowiedź Adamowi Krawcowi [w:] Mieszczanie, wasale, zakonnicy, red. B. Śliwiński, Malbork 2004 („Studia z Dziejów Średniowiecza”, nr 10), s. 466-468; J.C. Schmitt, Gest w średniowiecznej Europie, przeł. H. Zaremska, Warszawa 2006, s. 273-274. O obraźliwych gestach związanych z nieczystością ciała wspomniałam w tekście Brud i smród w świetle polskich, średniowiecznych źródet hagiograficznych - próba rozpoznania tematu, Gdańsk 2010 (,Studia Historica Gedanensia”, t. 1), s. 23-24. Prace wartościowe porównawczo: N. Schnitzler, „Unformliche zeichen' und ,freche Ungebarden”. Zur Ikonographie der Schande in spätmittelalterlichen Passionsdarsteeungen [w:] Körper-Geschichten. 
poświęcone właśnie temu zagadnieniu, tj. gestom zniewagi, które były używane dla wyrażenia pogardy, niechęci, drwiny lub gniewu, a tym samym naruszały cześć osoby obrażanej ${ }^{3}$.

Tekst jest przyczynkiem do obszerniejszego studium, w którym zostaną omówione wszelkie sposoby znieważania w późnośredniowiecznej Polsce, poświadczone przez przekazy pisane i przedstawienia ikonograficzne. Wątek zniewagi najczęściej pojawia się w źródłach, które dotyczą tematu Męki Pańskiej ${ }^{4}$, a zatem w narracjach o charakterze apokryficznym ${ }^{5}$ i ikonografii pasyjnej.

Szczególnie wartościowe dla omawianego tematu sa powstałe pod koniec XV w. w krakowskim klasztorze dominikanów Rozmyślania dominikańskie. Zabytek ten liczy 122 karty pergaminowe, na których oprócz tekstu znajduje się 117 miniatur ilustrujących poszczególne epizody Męki, w tym licznie sceny, w których Chrystus był poniżany. Rękopis pierwotny został częściowo zmyty i poprawiony w 1532 r., ta wersja stała się podstawą współczesnego wydania ${ }^{6}$.

Studien zur historischen Kulturforschung, hg. R. v. Dülmen, Frankfurt-Main 1996, s. 13-42; T. Wiślicz, Gest obraźliwy na wsi polskiej w XVII i XVIII wieku, „Przegląd Historyczny" 1997, t. 88, z. 34, s. 417-425.

3 Zob. W. Puciata, Ochrona czci w dawnem ustawodawstwie polskim, „Głos sądownictwa” 1936, s. 471-472. Por. współczesną terminologię prawną, np. A. Banach, Ochrona czci i godności osobistej w kodeksie karnym polskim, Kraków 1950; M. Surknot, Zniestawienie $i$ znieważenie $w$ polskim prawie karnym, Gdańsk 1982; W. Kulesza, Zniesławienie i zniewaga. Ochrona czci i godności osobistej człowieka w polskim prawie karnym - zagadnienia podstawowe, Warszawa 1984; Wojciechowski, Przestepstwa przeciwko czci i nietykalności cielesnej, Warszawa 2000.

4 J. Kopeć, Męka Pańska w religijnej kulturze polskiego średniowiecza. Studium nad pasyjnymi motywami i tekstami liturgicznymi, Warszawa 1975; W. Haug, B. Wachinger, Die Passion Christi in Literatur und Kunst des Spätmittelalters, Tübingen 1993; Z. Kliś, Pasja, Cykle pasyjne Chrystusa w średniowiecznym malarstwie ściennym Europy Środkowej. Katalog, Kraków 2006; The Passion Story from visual representation to social drama, ed. M. Kupfer, Pennsylvania 2008; A Schmiddunser, Körper der Passionen: die lebensgroße Liegefigur des toten Christus vom Mittelalter bis zum spanischen Yacente des Frühbarock, Regensburg 2008.

5 Narracje o charakterze apokryficznym (zwane też narracjami biblijno-apokryficznymi lub też często po prostu apokryfami) to utwory kompilacyjne, powstałe w okresie dojrzałego średniowiecza, w Polsce popularne w XV i XVI w.; M. Adamczyk, Biblijno-apokryficzne narracje $w$ literaturze staropolskiej do końca XVI w., Poznań 1980; E. Woźniak, Średniowieczne źródta do badania językowego obrazu męki pańskiej, „Rozprawy Komisji Językowej ŁTN” 2002, t. 47 s. 120-123.

${ }_{6}$ Rozmyślania dominikańskie, t. 1, wyd. i oprac. K. Górski, W. Kuraszkiewicz, Z. Rozanow (oprac. ikonograficzne), Wrocław 1965 [dalej: RD]; K. Górski, Analiza pisarska-metoda wydawnicza-zagadnienie autorstwa [w:] RD, s. 11-14; Z. Rozanow, Miniatury i iluminacje tekstu „Rozmyślań dominikańskich”[w:] RD, s. 18-38; D. Koza- 
Wśród staropolskich apokryfów okresu późnego średniowiecza najobszerniejsze jest Rozmyślanie przemyskie, w którym autor sporo miejsca - bo aż 250 rozdziałów - poświęcił historii Męki Pańskiej, niestety część ta jest niekompletna i kończy się na scenie „Ecce homo”. Według Wiesława Wydry, kopia, która przetrwała do naszych czasów, została sporządzona w trzecim dziesięcioleciu XVI w, zaś oryginał powstał prawdopodobnie w $1460 \mathrm{r}^{7}$

Niewątpliwie średniowieczne pochodzenie ma także Sprawa chędoga o Męce Pana Chrystusowej, świadczy o tym zachowana w zbiorach Biblioteki Czartoryskich w Krakowie pojedyncza karta tekstu utworu (tzw. Karta Rogawskiego) datowana na druga połowę $\mathrm{XV}$ w., całość jednak jest znana dopiero z odpisu kopisty, Wawrzyńca z Łaska, z 1544 r. $^{8}$

W publikacji została także wykorzystana jedna z pierwszych książek wydanych w języku polskim - Żywot Wszechmogacego Syna Bożego Pana Jezu Krysta (1522). Dzieło to bogato zdobione drzeworytami Hansa Schäufeleina jest kompilacją stworzona przez Baltazara Opeca (tłumacza i duchownego, absolwenta Uniwersytetu Krakowskiego), opartą głównie na łacińskim Meditiatones vitae Christi ${ }^{9}$.

Przy charakterystyce gestów zdecydowanie najbardziej są przydatne źródła ikonograficzne, przede wszystkim ze względu na pokrewieństwo semantyczne między gestem - czyli wizualnym sposobem komunikacji - a obrazem rejestrującym ten przekaz ${ }^{10}$. Poza tekstem

ryn, Kształt stylistyczny „Rozmyślań dominikańskich” na tle innych pasji staropolskich, Szczecin 2001; T. Michałowska, Literatura polskiego średniowiecza, Warszaw 2011, s. $746-747$.

7 Rozmyślanie przemyskie, t. 1-2, transliteracja, transkrypcja, podstawa łacińska, niemiecki przekład, wyd. F. Keller, W. Twardzik, Freiburg 2000 [dalej: RP]; W. Wydra., Historyczny i kodykologiczny opis rękopisu [w:] RP, s. 38; T. Michałowska, Literatura..., s. 747.

8 S. Vrtel-Wierczyński, Sprawa chędoga o męce Pana Chrystusowej $i$ Ewangelia Nikodema, Poznań 1933, [dalej: SCh]; T. Michałowska, Literatura..., s. 782.

9 Balzar Opec, Żywot Wszechmogacego Syna Bożego Pana Jezu Krysta, Stworzyciela i Zbawiciela rodzaju ludzkiego, Kraków 1522 [dalej: ŻWSB], http://ebuw. uw.edu.pl/dlibra/docmetadata?id=107549\&from=publication [dostęp 8.05.2017]. W tym samym roku ukazało się drukiem kolejne wydanie tego dzieła pod innym tytułem, zob. Żywot Pana Jezu Krysta Stworzyciela i Zbawiciela rodzaju ludzkiego, wyd. J. Haller, Kraków 1882; T. Michałowska, Literatura..., s. 124, 901.

10 P. Mrozowski, Gest władcy w ikonografii polskiego średniowiecza [w:] Imagines poteststis. Rytuaty, symbole i konteksty fabularne władzy zwierzchniej. Polska X-XVw., Warszawa 1994, s. 60; J.C. Schmidt, Gest..., s. 19. 
oraz miniaturami i drzeworytami, które znalazły się w wymienionych wyżej narracjach apokryficznych, analizie posłużą także inne zabytki ikonograficzne dotyczace tematyki pasyjnej, chodzi tu o gotyckie malarstwo miniaturowe, ścienne oraz tablicowe ${ }^{11}$. Treść dzieł sztuki była zgodna z ogólnie panująca w średniowieczu ideologia i sprowadzała się do rzeczy świętych, bazując przede wszystkim na Piśmie Świętym, stąd tak liczne przedstawienia dotyczące Męki Chrystusa ${ }^{12}$.

Przedmiotem badań są gesty zniewagi, jakie wykonywali względem Chrystusa jego oprawcy, w związku z tym pojawia się pytanie, na ile twórcy średniowieczni jedynie odtwarzali zawarte w Piśmie Świętym i apokryfach informacje, a na ile uzupełniali je własna wizją wydarzeń. Ważne jest także, w jakim stopniu powtarzali utarte schematy oraz czy istniała jakaś określona metoda przedstawiania motywów biblijnych. Zapewne nie stosowaliby niezrozumiałych dla odbiorcy znaków. Wszelkie zachowania będące aktem zniewagi, które pojawiały się w relacjach pisanych czy w ikonografii, musiały być rozpoznawalne dla ogólu. Szczególnie interesujące będą te treści, które są dodatkiem, swoistym urozmaiceniem kanonicznej narracji. Niektóre uogólnienia pojawiające się w Ewangeliach dały bowiem średniowiecznym artystom możliwość ich własnej interpretacji ${ }^{13}$.

11 T. Dobrzeniecki, Malarstwo tablicowe. Katalog zbiorów, Warszawa 1972 [dalej: Dobrzeniecki]; A. Karłowska-Kamzowa, Malarstwo ślaskie 1250-1450, WrocławWarszawa-Kraków-Gdańsk 1979; A.S. Labuda, Malarstwo tablicowe w Gdańsku w 2 pot. XVw., Warszawa 1979; J. Gadomski, Gotyckie malarstwo tablicowe Małopolski, t. 1: 1420-1470, Warszawa 1981; t. 2: 1460-1500, Warszawa 1988; t. 3: 1500-1540, Warszawa-Kraków 1995, [dalej: Gadomski]; B. Miodońska, Małopolskie malarstwo ksiażkowe 1320-1540, Warszawa 1993; Sztuka na Ślasku XII-XVI w. Katalog zbiorów, red. B. Guldan-Klamecka, Wrocław 2003; Malarstwo gotyckie w Polsce, t. 3: Album ilustracji, red. A.S. Labuda, K. Secomska, Warszawa 2004 [dalej: MGP]; Muzeum Narodowe w Warszawie. Arcydzieła malarstwa, red. E. Folga-Januszewska, Warszawa 2005 [dalej: MNW]. Porównawczo: J.H. Marrow, Passion Iconography in Northern European Art of the Late Middle Ages and Early Renaissance: A Study of the Transformation of Sacred Metaphor into Descriptive Narrative, Brussels 1979. Wybrane przedstawienia ikonograficzne wykorzystane w tekście zostały umieszczone w katalogu internetowym: https://pl.pinterest.com/weronikakonkol/gesty-zniewagi-ikonografia-do-artyku\%C5\%82u/ [dostęp 8.05.2017].

12 M. Otto-Michałowska, Gotyckie malarstwo tablicowe w Polsce, Warszawa 1982, s. 6; W. Smoleń, Ilustracje świat kościelnych w polskiej sztuce, Lublin 1987, s. 98 i nn.

13 J.H. Marrow, Inventing the Passions in the late Middle Ages [w:] The Passion Story from visual representation to social drama, ed. M. Kupf, Pennsylvania 2008. 
Niezbędne jest zatem przeanalizowanie tekstu Pisma Świętego ${ }^{14}$, zwłaszcza fragmentów dotyczących Męki Pańskiej ${ }^{15}$, z uwzględnieniem opisów obraźliwych zachowań. Analiza ta będzie stanowiła punkt odniesienia do dalszych dociekań.

W Ewangeliach jest mowa o sześciu ${ }^{16}$ okolicznościach naigrywania się z Chrystusa: w nocy po pojmaniu, ze strony straży arcykapłańskiej (Łk 22, 63-64) później u Kajfasza na spotkaniu Sanhedrynu (Mt 26, 67-68; Mk 14, 65; J 18, 22-24); następnego dnia u Heroda (Łk 23, 11); w pretorium u Piłata przed zatwierdzeniem wyroku (J 19, 2-3); w pretorium po zatwierdzeniu wyroku (Mt 27, 27-31; Mk, 15, 16-20) oraz podczas ukrzyżowania (Mk 15, 29-32; Mt 27, 39-44; Łk 23, 35-45). Kolejność wydarzeń nie jest jednakowa w poszczególnych Ewangeliach. Pierwsze szyderstwa według św. Łukasza miały miejsce jeszcze zanim Chrystus był przesłuchany przez sanhedryn i miały być formą rozrywki pilnujących go strażników. Kpiny były swego rodzaju grą w chowanego, zakryto Jezusowi oczy i kazano mu zgadywać, kto go uderzył: „Tymczasem ludzie, którzy pilnowali Jezusa, naigrawali się z Niego i bili Go. Zasłaniali Mu oczy i pytali: «Prorokuj, kto Cię uderzył». Wiele też innych obelg miotali przeciw Niemu" (Łk 22, 63-64). U pozostałych synoptyków wszystko miało mieć miejsce po procesie i skazaniu. Wedle Ewangelii Mateusza (Mt 27, 27-31) oraz Marka (Mk 15, 16-22), straż rzymska dała upust swojej brutalności, naigrywając się z Chrystusa jako króla Żydów. Święty Jan mówi o „cierniem ukoronowaniu” już $\mathrm{w}$ trakcie procesu, po czym następuje prezentacja Jezusa ludowi jako wyśmianego króla (J 19, 2-5). Historia męki nie informuje, w jaki sposób odbyło się biczowanie Chrystusa. Dokładniej natomiast jest

${ }_{14}$ Pismo Święte Starego i Nowego Testamentu, w przekł. z jęz. oryg. oprac. zespół biblistów polskich z inicjatywy Benedyktynów Tynieckich; red. K. Dynarski, M. Przybył, red. nauk. A. Jankowski i in., tłum. ksiąg W. Borowski i in., Pallotinum, Poznań 2003.

15 Temat Pasji Chrystusa doczekał się bardzo bogatej literatury, w której były omawiane także wątki upokarzania i drwin, zob. H. Langkammer, Wprowadzenie i komentarz do ewangelicznych opisów męki pańskiej, Lublin 1975; C.M. Martini, Męka Jezusa Chrystusa według czterech Ewangelii, tłum. S. Wąsik i. in., Kraków 2003; F. Boscione, Gesty Chrystusa, Kraków 2004; I. Potterie, Męka Jezusa Chrystusa wedtug Ewangelii Jana, tłum. T. Kukułka, Kraków 2006; Męka Pana naszego Jezusa Chrystusa wedtug. św. Mateusza, komentarz teologiczno-biblijny, red. A. Paciorek, komentarz ikonograficzny A. Kramiszewska, Lublin 2007; B. Maggioni, Ewangeliczne opowieści o męce pańskiej, Kraków 2010.

16 Nie o pięciu, jak podał E. Dąbrowski, Proces Chrystusa w świetle historyczno-krytycznym, Poznań-Warszawa-Lublin 1965, s. 211. 
opisana scena, która miała miejsce bezpośrednio po biczowaniu, wtedy także Żydzi naigrywali się z Chrystusa. Żołnierze w szyderczy sposób odgrywali scenę hołdu, ubrali Jezusa w purpurową szatę, dali mu berło z trzciny i wbili na jego głowę koronę spleciona z cierni, jest także mowa o prześmiewczym przyklękaniu przed Chrystusem ${ }^{17}$. Widowisku towarzyszyły szydercze słowa, uderzenia w głowę i policzkowania, o czym piszą Mateusz (Mt 26, 67), Marek (Mk 14, 65) oraz dwukrotnie św. Jan. U tego ostatniego Chrystus jest uderzony po raz pierwszy w scenie przed Annaszem, przez jednego ze sług arcykapłana (J 18, 22-24), następnie u Piłata, gdzie żołnierze biją Jezusa przed ukazaniem Go ludowi żydowskiemu (J 19, 1-3). W czasie ukazania, kiedy to padają słowa „Oto człowiek” (Ecce homo), poza nawoływaniami ludu, aby ukrzyżować Chrystusa, nie pojawiają się w Piśmie Świętym żadne wzmianki o zniewagach. Fakt o tyle istotny, że inaczej motyw ten będą przedstawiać średniowieczni artyści, o czym szerzej poniżej. Elementem wspólnym Ewangelii synoptycznych jest opluwanie $^{18}$, które wyraża nie tylko kpinę, ale i pogardę. U św. Łukasza wzmianka o tej formie zniewagi pojawia się tylko przy okazji zapowiedzi męki i zmartwychwstania, jeszcze przed wydarzeniami w Jerozolimie (Łk 18, 31). Mateusz i Marek wspominają o pluciu na Chrystusa po wyroku Najwyższej Rady (Mt 26, 67; Mk 14, 65) oraz po wydaniu wyroku przez Piłata, przed Drogą Krzyżową (Mt 27, $30 ;$ Mk 15, 19) ${ }^{19}$. Ostatnia scena wyszydzania Chrystusa ma miejsce pod krzyżem (Mt 27, 39; Mk 15, 29; Łk 23, 35-39): „Ci zaś, którzy przechodzili złorzeczyli mu potrząsając głowami i mówiąc: «Ty, który burzysz świątynie i w trzech dniach ja odbudowujesz wybaw samego siebie. Jeśli jesteś Synem Bożym zstap z krzyża»"(Mt 27, 39-41). Podobnie mieli się zachować arcykapłani i złoczyńcy skazani wraz

17 Według H. Langkammera podobne praktyki szydercze znane są z terenów Palestyny, np. za namiestnika Flakkusa w Aleksandrii w 38 r., tłum dopuścił się wyszydzenia króla Agrypy I. Przystroiwszy chorego psychicznie człowieka imieniem Karabas w diadem i łodyge papirusu jako berło, oddawał mu hołd królewski, wołając „mare” tzn. „panie”. Analogię można znaleźć w opisie Plutarcha (Pomp. 24, 7-8), gdzie piraci szydząc z pewnego rzymianina, obchodzili się z nim ze wszelkimi honorami, w końcu wyrzucili go do morza. Zob. H. Langkammer, Wprowadzenie i komentarz..., s. 94; Męka Pana..., s. 81.

18 Wspólna nazwa dla Ewangelii według św. Mateusza, według św. Marka (uważana za najstarsza) i według św. Łukasza. Ewangelie te są łączone z uwagi na znaczne podobieństwo relacji w porównaniu z odmiennym sposobem ujęć Ewangelii według św. Jana.

19 Por. F. Boscione, Gesty..., s. 128-129. 
z Chrystusem. Wrogie Jezusowi wypowiedzi przechodniów poprzedzone są potrząsaniem głową, gest ten stanowi w Biblii typowy gest szyderstwa ${ }^{20}$ (por. Ps 22, 8).

Pod względem szczegółowości opisów zachowań znieważających Ewangelie nieznacznie się od siebie różnia. Najwięcej dowiadujemy się z Ewangelii św. Mateusza, który mocniej niż św. Marek uwydatniał wszystko, co podkreśla upokorzenie Jezusa. Święty Łukasz opuszczał niektóre nazbyt poniżajace szczegóły, na przykład plucie w twarz podczas znęcania się czy scenę szyderczego hołdu, nie pomniejszało to jednak głębi hańbiących praktyk, jakim poddany został Jezus. Najmniej informacji na temat znieważania Chrystusa podaje św. Jan piszący jedynie o policzkowaniu i przybraniu w purpurowy płaszcz podczas koronowania.

Poza Ewangeliami należałoby jeszcze odnieść się do tych fragmentów Pisma Świętego, w których główne postacie utożsamiane są z Chrystusem ${ }^{21}$. Między innymi do pierwszej i zarazem najdłuższej księgi prorockiej Starego Testamentu - Księgi Izajasza. Upokorzenia, jakie przyjmuje przedstawiona tam postać Sługi Pana, oraz jej postawa zostają w Nowym Testamencie odniesione do osoby Jezusa: „Podałem grzbiet mój bijacym i policzki moje rwącym mi brodę. Nie zasłoniłem mojej twarzy przed zniewagami i opluciem" (Iz 50, 6). Odniesienia do Mesjasza znaleźć można także we wspomnianym już Psalmie Dawidowym „Szydzą ze mnie wszyscy, którzy na mnie patrza, rozwierają wargi, potrząsają głową" (por. Ps 22,8$)^{22}$.

Temat Męki Pańskiej był podejmowany także w Ewangeliach apokryficznych, które w średniowieczu traktowano jako ważne dokumenty historyczne ${ }^{23}$. Podstawowymi utworami w tej grupie sa Ewangelia Piotra oraz Ewangelia Nikodema - tzw. Akta Piłata, jednak nie wzbogacają one ewangelicznych opisów poniżania Chrystusa ${ }^{24}$.

20 Męka Pana..., s. 89.

${ }^{21}$ O typologicznej obecności Chrystusa w osobach Starego Testamentu zob. S. Kobielus, Concordia Novi et Veteris Testamenti. Zapowiedź dzieła odkupienia i jego spetnienie $w$ teologii $i$ sztuce średniowiecza, Poznań 2013, s. 11-17.

22 Również autorzy średniowieczni odwoływali się do proroctw starotestamentowych, co podkreślali w tekstach, np.: RP, s. 687, RD, s. 138 „y w<ype>lnylo fzye proroczltwo Izaiafa” lub RD, s. 142 „A tv wypelnylo fyæ prorocztwo Davida krola”.

23 Apokryfy sensu stricto, zwane też właściwymi, to utwory powstałe od około 200 r. przed Chrystusem do około IV w. po Chrystusie, niezaliczane przez Kościół do tzw. kanonu.

24 Apokryfy Nowego Testamentu. Ewangelie apokryficzne, cz. II, red. M. Starowieyski, Kraków 2003, s. 618. Tu opis ukoronowania cierniem z odzianiem w purpurowy 
Wymienione wyżej ewangeliczne opisy opluwania, policzkowania, bicia, wyciagania za brodę, potrząsania głowa, a także obelgi i drwiny - w tym prześmiewcze hołdy - znalazły odzwierciedlenie w wymienionych wyżej źródłach średniowiecznych.

Najczęściej opisywanym w średniowiecznych narracjach apokryficznych sposobem znieważania było opluwanie ${ }^{25}$, wzmiankowane niemalże 60 razy $^{26}$. Oprawcy Chrystusa mieli upokarzać Go, plując mu „śmierdzącymi ślinami” w twarz ${ }^{27}$, co według Rozmyślań dominikańskich robili z taką intensywnościa, że aż plwociny spływały po szczęce na ziemię, a oczu wcale nie było widaćc ${ }^{28}$. Wątek ubliżającego opluwania pojawiał się także w średniowiecznej ikonografii ${ }^{29}$. Na przykład w miniaturach Rozmyślań dominikańskich, pachołkowie drwią w ten sposób z Chrystusa w scenach przed Kajfaszem ${ }^{30}$, Annaszem $^{31}$ (ryc.1.) oraz przed Herodem ${ }^{32}$. Co interesujące, opluwanie było tak oczywistym sposobem znieważania Chrystusa, że stanowiło jeden z elementów Arma Passionis. Wizerunki plującej głowy

płaszcz, plucie, policzkowanie. Jezus w tych przekazach zachowuje się tak, jak gdyby nie cierpiał, wydaje się iż autorzy sądzili, że Syn Boży nie jest zdolny do odczucia bólu, (EwPt 4,10), zob. H. Langkammer, Wprowadzenie i komentarz..., s. 129.

25 Dokładniej o opluwaniu i innych obraźliwych gestach związanych z nieczystościami, tj. o wymiotowaniu, wysiąkaniu nosa, oblewaniu nieczystościami i obrzucanie błotem, zob. W. Konkol, „A oni leja nań nieczystymi pomyjami”. O roli zmystów w średniowiecznych sposobach znieważania, „Teka Historyka” 2016, z. 51, s. $103-126$.

26 RD, s. 77, 98, 102, 103, 106, 112, 124, 130, 146, 156, 184; SCh, s. 47, 55, 58, 76, 83, 85; RP, s. 647, 651, 664, 666, 676, 687, 699, 728, 729, 730, 739, 757; ŻWSB, s. LXVII, LXXI, LXXV, LXXVI, LXXVIII, LXXXVIII, LXXXX.

27 Niekiedy też sprecyzowano, że celowali prosto w oczy, zob. RD, s. 102, 106, 124, 156; w usta, zob. RD, s. 102, 103, 106, 124; ŻWSB, s. LXXV, LXXVI bądź pod nos, zob. RP, s. 664.

${ }_{28}$ RD, s. 102, podobny opis zob. RP, s. 664, a także w kazaniu Peregryna z Opola (XIII/XIV w.), który stwierdza, że Jezus był tak bardzo opluty, iż jego własna matka $\mathrm{z}$ trudem go poznawała, Peregrini de Opole, Sermones de tempore et de sanctis, red. R. Tatarzyński, Warszawa 1997, s. 583; Peregryn z Opola, Kazania de tempore $i$ de sanctis, przeł. J. Mrukówna, weryfikacja przekładu i oprac. E. Deptuchowa, L. Szelachowska-Winiarzowa, Z. Wanicowa, red. nauk. J. Wolny, Kraków-Opole 2001, s. 462.

29 Gadomski, t. 1, il. 114, 115, t. 2, il. 74; MGP, il. 69, 291; RD, s. 89, 103, 107; KZSWP, t. 4, cz. III, 2, il. 325.

$\begin{array}{ll}30 & \text { RD, s. } 107 . \\ 31 & \text { RD, s. } 91 .\end{array}$

32 Ibidem, 125. 
umieszczone wśród narzędzi męki otaczających udręczonego Zbawiciela są elementem spotykanym w sztuce niemieckiej od początku XIV w., a od pierwszej ćwierci stulecia, znanym także w Europie Środkowej ${ }^{33}$. Przykłady tego typu przedstawień w granicach Polski znajdujemy na malowidłach ściennych ${ }^{34}$ oraz $\mathrm{w}$ malarstwie tablicowym ${ }^{35}$. Opluwanie Chrystusa było jedynym wzmiankowanym przez Ewangelistów gestem, który wiązał się nieczystościa, tj. ślina. W omawianych źródłach średniowiecznych poniżanie Chrystusa polegało także na zmuszaniu do kontaktu z innymi brudami i wydzielinami ludzkiego ciała ${ }^{36}$. Według Rozmyślań dominikańskich pachołkowie ,jęli sprosnie rzygać w usta Jezusowe rozdzierając je i takeż pod nos jego" 37 . Informacje o takim zachowaniu pojawiają się też w kilku innych miejscach ${ }^{38}$, a sceny w których oprawcy wymiotują na Chrystusa, zostały z wielką dokładnością zilustrowane w miniaturach ${ }^{39}$.

Kolejnym nietypowym sposobem zniewagi, pojawiającym się w średniowiecznych przedstawieniach plastycznych, było wysiąkanie nosa $\mathbf{a}^{40}$. Taki gest możemy znaleźć na obrazie Naigrywanie (1468) krakowskiego malarza Mikołaja Haberschracka ${ }^{41}$ oraz na dwóch miniaturach Rozmyślań dominikańskich ${ }^{42}$. W narracjach

33 G. Jurkowlaniec, Chrystus umęczony. Ikonografia w Polsce od XIII do XVI wieku., Warszawa 2001, s. 75; G. Górny, Świadkowie tajemnicy, Warszawa 2012, s. 31. Na temat średniowiecznych przedstawień typu Arma Christi powstała ostatnio obszerna, interdyscyplinarna praca amerykańskich badaczy: The Arma Christi in Medieval and Early Modern material culture: objects, representation and devotional practice. With a Critical Edition of 'O Vernicle', eds. L.H Cooper; A. Denny-Brown, Farnham 2013; o opluwaniu zob. ibidem, s. 104-105, 183-186, 222.

${ }_{34}$ Np. w Biejscach (1370-1380), MGP, il. 96; G. Jurkowlaniec, Chrystus umęczony..., s. 167; w Pogorzeli (2 ćw. XV w.) MGP, il. 291; w Ziębicach (1481-1482), MGP, il. 69.

35 Np. Chrystus Bolesny i Matka Bolesna, obraz z Brzegu (1443), ob. Muzeum Narodowe w Warszawie, Dobrzeniecki, il. 64; MNW, s. 99; Gadomski, t. 1, il. 114; MGP, il. 291; Chrystus Bolesny, skrzydło tryptyku, Maciejowice (1450-1460), Gadomski, t. 1, il. 115 .

$36 \quad$ W. Konkol, Brud i smród..., s. 23-25.

37 RD, s. 102. Transkrypcja za: Rozmyślania dominikańskie [w:] Caty świat nie pomieścił by ksiag. Staropolskie opowieści i przekazy apokryficzne, wyd. W.R. Rzepka, R. Wydra, Warszawa-Poznań 1996, s. 319.

38 RD, s. 110; RP, s. 664; ŻWSB, s. LXXVI.

39 RD, s. 103, 111.

40 RD, s. 107, 111; MGP, il. 490 (także Gadomski, t. 2, il. 73).

${ }^{41}$ MGP, il. 490. Na gest zwrócił uwagę m.in. W. Smoleń, zob. idem, Ilustracje..., s. 99.

42 RD, s. 107, 111. 
apokryficznych jest także mowa o innych sposobach ubliżania, do których wykorzystywano nieczystości, było to oblewane pomyjami ${ }^{43}$, obrzucanie gnojem ${ }^{44}$, błotem ${ }^{45}$ oraz wrzucanie w błoto ${ }^{46}$.

Drugim gestem obrazy, o którym mówią Ewangelie, a który był bardzo akcentowany w średniowiecznych narracjach apokryficznych, jest policzkowanie, czyli uderzenie w twarz otwarta dłonia. Zachowanie takie jest ponadczasowym - używanym w każdej epoce historycznej - demonstracyjnym okazaniem braku szacunku. Informacje o „dawaniu policzków” są jednym z częstszych zarzutów pojawiających się w XIV- i XV-wiecznych rotach sądowych ${ }^{47}$, nie dziwi zatem ich znaczna liczba w średniowiecznych historiach pasyjnych ${ }^{48}$. Tam „policzki” określane były często jako: wielkie ${ }^{49}$, ciężkie $^{50}$, okropne $^{51}$ lub silne ${ }^{52}$, co było podkreśleniem fizycznego cierpienia Chrystusa. Ocenę przeżywanej boleści pozostawiono także wyobraźni czytelnika, zwłaszcza w takich fragmentach, jak w tym z Rozmyślań dominikańskich, w którym mowa o policzkach w żelaznych rękawicach ${ }^{53}$. Wśród szczegółów, o jakie źródła średniowieczne uzupełniły treść Ewangelii, jest także podanie z imienia sługi Annasza, który uderzył Jezusa w twarz podczas przesłuchania u arcykapłana. Miał nim być Malkusz (Malchus) - wcześniej Chrystus go uzdrowił, po tym jak św. Piotr obciął mu ucho. Wedle Rozmyślania przemyskiego „wielki policzek" wymierzony przez Malkusza był jednoznaczny z powiedzeniem do Jezusa: „Ty spro<s>ny człowiecze” ${ }^{54}$. Najpewniej właśnie gest

\footnotetext{
43 Ibidem, s. 110, 112, 124, 126, Sch 85; miniatury: RD, s. 107, 111.

${ }_{44}$ ŻWSB, s. LXXVI.

45 RD, s. 116, 128, 184.

46 Towarzyszyły temu drwiny oprawców, którzy sugerowali Chrystusowi, aby sobie poleżał, bo się napracował, RD, s. 110.

${ }_{47} \mathrm{~Np}$. Wielkopolskie roty sqdowe XIV-XV wieku, t. 1: Roty poznańskie, zebr. i oprac. H. Kowalewicz, W. Kuraszkiewicz, Warszawa 1974, nr 561 (1404 r.), 786 (1408 r.),1651 (1433r. ); Zapiski i roty polskie XV-XVI wieku: z ksiag sadowych ziemi warszawskiej, oprac. W. Kuraszkiewicz, A. Wolff, Kraków 1950 („Prace Komisji Językowej” nr 36), nr 286 (1428 r.), 847 (1434 r.), 2755, 2764.

48 RD, s. 77, 83 86, 88, 90, 98, 100, 104, 106, 114, 120, 122, 124, 152, 126, 157, 160, 182; SCh 47, 55, 58, 83; RP, s. 646, 647, 676, 682, 702, 710, 728, 729, 730, 802; ŻWSB, s. LXVII, LXXI, LXXIIII, LXXVI, LXXXII, LXXXVIII.

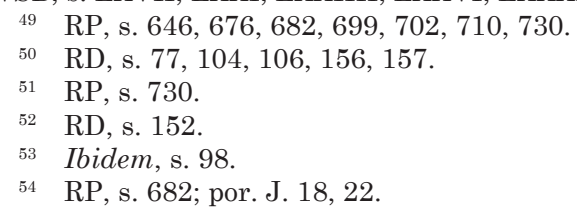


policzkowania miały przedstawiać symboliczne dłonie umieszczane wśród innych narzędzi męki na obrazach Arma Passioni ${ }^{55}$. W ikonografii Męki Pańskiej na wielu przedstawieniach postacie otaczajace Chrystusa mają uniesione w zamachu ręce (np. ryc. 1) ${ }^{56}$. Część z nich zapewne miała również oznaczać policzkowanie, tu jednak możliwości jest więcej, w źródłach pisanych jest też mowa o biciu pięścią w twarz, uderzaniu w szyję (,poszyjkach”) czy „tłuczeniu świętej głowy” ${ }^{57}$.

Tak jak w Ewangeliach, tak i w źródłach średniowiecznych pojawił się wątek szyderczej zabawy pachołków, którzy zawiązawszy Chrystusowi chustę ${ }^{58}$ na oczy, kpili z Niego, każąc Mu zgadywać, kto Go uderzył ${ }^{59}$. Według Rozmyślania przemyskiego oprawcy „poczęli pluwać na jego święte oblicze i poczęli policzki jemu dawać, a niektórzy w jego święte lice bili, które byli przedtem zawiązali, rzekac: «Prorokuj Kryste, kto jest, kto cię uderzył»"60. O tym epizodzie Męki Pańskiej wspominał także Peregryn z Opola w kazaniu na Niedzielę Palmowa, porównując zachowanie oprawców do popularnej dziecięcej zabawy: „I naigrywali się z niego tak jak to czynią chłopcy, bawiąc się w grę zwaną cuzzebut"61.

Do zachowań agresywnych stosowanych wobec Chrystusa, będących jednocześnie zniewaga, zaliczyć należy wyciąganie za włosy, obraźliwy gest, który w omawianych źródłach średniowiecznych występuje najliczniej (ponad 100 razy!) ${ }^{62}$. Zdecydowanie rzadziej

55 Gadomski, t. 1, il. 114, 115.

56 Np. MGP, il. 817; RD, s. 87, 91, 99, 103,105, 107, .

57 Np. RD, s. 82, 86, 120, 140, 158, 182, 106; RP, s. 651, 654, 664, 699, 701, 702, $729,730,739$.

${ }_{58}$ Wizerunki zwiniętej chusty pojawiały się na przedstawieniach typu Arma Christii obok innych narzędzi męki, zob. np. Gadomski, t. 1, il. 34.

59 RD, s. 106, 157; SCh 55, 76; RP, s. 710, 728; ikonografia: MGP, il. 817; RD, s. $105,107,153$, ŻWSB, s. 165.

60 RP, s. 728.

61 Peregrini de Opole, Sermones, s. 104; Peregryn z Opola, Kazania, s. 133. Na motyw „cuzzebut” zwrócił uwagę M. Hervé, zob. tenże, Un médiateur culturel au début du XIVe siècle: le prédicateur polonais Peregrin d'Opole [w:] Actes des congrès de la Société des historiens médiévistes de l'enseignement supérieur public. 32e congrès, Dunkerque, 2001. Les échanges culturels au Moyen Âge, s. 146, http://www.persee.fr/ web/revues/home/prescript/article/shmes_1261-9078_2002_act_32_1_1811 [dostęp 8.05.2017].

62 RD, s. 80, 82, 86, 88, 100, 102, 106, 110, 124, 126, 142, 157, 188; SCh 47; RP, s. 647, 651, 669, 701, 711, 730; ŻWSB, s. LXVII, LXVIII, LXXIII, LXXIIII, LXXV, LXXVI, XXXII, XXXVIII; ikonografia: Dobrzeniecki, il. 35; 84 A1 b; 72 B, 73 B2, 77 D2, 81 A2, 82 A1, 83 B2 a; Gadomski, t. 1, il. 34, 115; t. 2, il. 73, 152, 171, fragm. 380, 180, 371; t. 3, il. 112, 113, 189; A. Karłowska-Kamzowa, Malarstwo..., s. 73, 78; 
pojawia się motyw szarpania brody (kilkanaście wzmianek) ${ }^{63}$. O ile o „rwaniu brody” dowiadujemy się z Pisma Świętego (Iz, 50, 6), to nie znajdujmy tam komentarza o wyciaganiu Chrystusa za włosy. Oba gesty można natomiast odnaleźć we wszystkich wyróżnionych wyżej narracjach, zwykle towarzyszą im inne zachowania znieważajace, tak jak w Rozmyślaniu przemyskim, gdzie św. Piotr miał relacjonować z płaczem to, czego był świadkiem: „Bom widział, jak na jego święte lice błotem miotano i plwano, i policzki dawano wielkie, rwąc za święte włosy, zawiązując jego święte oczy i bili poszyjki”"64. O tym, że wyciaganie za włosy mogło być wykonywane z różną intensywnościa, świadczą używane czasowniki, za włosy bowiem nie tylko ciagnięto $^{65}$, ale i targano ${ }^{66}$, podnoszono ${ }^{67}$, siepano ${ }^{68}$, włóczono ${ }^{69}$, trzymano $^{70}$, a przede wszystkim rwano ${ }^{71}$. Skuteczność wyrywania włosów poświadczają drobiazgowe opisy, że rwano je „razem ze skórą aż było kości widać na głowie"72. Podobnie wyglądało to w przypadku szarpania za brodę - we wszystkich analizowanych przekazach jest podkreślony fakt, że za brodę nie tylko targano, ale i wyrywano z niej włosy. Pojawiło się nawet w tym kontekście szyderstwo, jeden ze znęcających się w ten sposób oprawców miał powiedzieć do Chrystusa: „oto zlicz, ilem wyrwał twojej brody" "3 . Opisy wyciagania Chrystusa za brodę pełne były drastycznych szczegółów, czynność ta miała być wykonywana wedle Rozmyślania przemyskiego z gniewem i wielka siła, gdyż „się jemu [Chrystusowi] wszystki zęby poruszyły i usta

Z. Kliś, Pasja..., il. 61i, 50k; KZSWP, t. 4, cz. I, il. 452; t. 5, z. 10, il. 219; MGP, il. 69, 291, 355, 356, 370, 490, 803, 549, 951, 1178; Sztuka na Ślasku XII-XVI w...., il. 119a, 119b; RD, s. 77, 81, 91, 97, 99, 105, 107, 115, 121, 123, 125, 127, 129, 131, 137, 139, 141, 151, 153, 183; ŻWSB, s. 165, 186. Jedne z ciekawszych przedstawień, na których widać wyraźnie wyciaganie za włosy znalazły się na obrazach ołtarza w Szydłowcu (ok. 1510), zob. S. Markiewicz, Późnogotycki ołtarz Wniebowzięcia Najświętszej Maryi Panny w Szydtowcu, Radom 2006, s. 38-40.

63 RD, s. 90, 102, 124, 188; SCh, s. 47; RP, s. 651, 662, 676, 701,730; ŻWSB, s. LXXV, LXXVI; ikonografia: MGP, il. 817; RD, s. 91, 103, 125; KZSWP, t. 4, cz. III, 2, il. 325 .

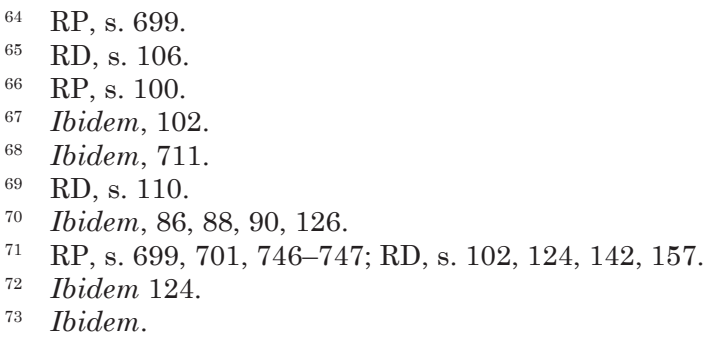


ociekły”"74, a w relacji dominikańskiej „rwano brodę, trzęsąc ją aż zęby szczekotały"75. Według tych źródeł za włosy i brodę chwytano także w praktycznym celu, aby unieruchomić głowę, co dawało możliwość swobodnego bicia po twarzy. Ten rodzaj naruszenia nietykalności, choć był środkiem do wykonania innego gestu, również należy traktować jako ujmujący godności, gdyż demonstracyjnie zmuszał do uległości ${ }^{76}$. Przykładem wyciagania za włosy i brodę jest miniatura z Rozmyślań dominikańskich, na której trzech pachołków Annasza znęca się nad związanym Chrystusem, bijąc go, kopiąc i szarpiąc za włosy (ryc. 1) ${ }^{77}$. Średniowieczne polskie narracje apokryficzne podejmujace temat Męki Pańskiej były bogate w szczegóły, które nie znajduja się w kanonicznej wersji. Sytuacje tę tłumaczy Baltazar Opec, według którego Chrystus doświadczył tak wiele złego ze strony swych oprawców „iż swieci ewanielistowie napisać się tego sromali” ${ }^{78}$. Zahamowań takich nie mieli ani autorzy omawianych średniowiecznych historii pasyjnych, ani twórcy przedstawień plastycznych poruszających tę tematykę. Wśród przedstawianych tam obraźliwych gestów, najcięższe wydają się takie, które w swej wymowie nawiązują do seksualności czy też szeroko pojętej intymności człowieka. Gesty zniewagi o charakterze obscenicznym odnoszą się do tego zagadnienia w dwojaki sposób: bezpośrednio - przez wykorzystanie wstydliwych części ciała, na przykład przez ich pokazywanie, bądź pośrednio - symbolicznie. W tym drugim wypadku szczególnie ważna jest symbolika falliczna, którą przypisywano palcom, językowi i nosowi - gdyż to ona stała się podstawą większości obscenicznych gestów.

W obszernym Dictionary of Symbols pod hasłem finger zostały omówione obsceniczne znaki wykonywane za pomocą palca bądź palców. Autor hasła sugeruje, że pokazanie „figi” to znaczeniowo ten sam gest co włożenie palca w usta, dotknięcie nim nosa, pokazanie języka czy wystawienie środkowego palca. Wszystkie łączy wspólna konotacja seksualna, różnią się jedynie formą ${ }^{79}$. Generalizując, można

74 RP, s. 662; także [w:] ŻWSB, s. LXVIIII.

75 RD, s. 90.

76 Tak uważa także K. Banek, który po prześledzeniu motywu trzymania za włosy w sztuce starożytnej stwierdził, że gest poza znaczeniem praktycznym miał też wymiar symboliczny, zob. idem, Opowieść o włosach. Zwyczaje-rytuaty-symbolika, Warszawa 2010, s. 136-138.

77 RD, s. 91.

78 ŻWSB, s. LXXV.

79 A. de Vries, Dictionary of symbol, Amsterdam-London, 1974, s. 184. 
stwierdzić, że nieprzyzwoite gesty najczęściej oznaczają stosunek płciowy bądź genitalia ${ }^{80}$, tym samym mają kojarzyć się z czymś nieczystym, wstydliwym, złym, czymś gorszej kategorii. Jednocześnie to co symbolizuja, z uwagi na nagość czy fizjologię, budzi i budziło pewną śmieszność. W związku z tymi gesty obsceniczne były używane przez wieki jako znaki obronne przed złymi mocami czy przed urokiem („,złe oko”) ${ }^{81}$. Wierzono bowiem, że można skutecznie z nimi walczyć poprzez ośmieszenie. Z czasem w zapomnienie odeszła geneza powstania tychże gestów, a pozostało samo skojarzenie sytuacyjne, stąd wykorzystanie ich w celu zadrwienia i poniżenia.

Gestem obscenicznym, który najczęściej przypisywano w średniowieczu oprawcom Chrystusa, było wytykanie języka. W znaczeniu symbolicznym język jest substytutem męskiego członka ${ }^{82}$. O tym, że był kojarzony ze sprośnościa, świadczy choćby pojawianie się tej części ciała w obscenicznych przedstawieniach diabła - personifikacji nieczystości. Przykładem moga być diabły z powstałego około 1504 r. poliptyku św. Jana Jałmużnika, który zdobił ołtarz w kościele św. Katarzyny w Krakowie ${ }^{83}$. W scenie ze św. Eufraksja rabiąca drwa nagi diabeł ma w kroczu twarz z bardzo długim, lubieżnie wystawionym językiem. Zaś na kwaterze ze świętą u studni postać diabła, również naga, ma obwisłe piersi i aż dwie dodatkowe twarze z wytkniętymi językami - jedną w kroczu, drugą na pośladkach $^{84}$. W tematyce pasyjnej gest wysuniętego języka pojawiał się najczęściej w scenach Naigrywania, Koronowania cierniem, Ukazania Chrystusa i Niesienia krzyża (np. ryc. 1 i 2$)^{85}$. Podczas wnikliwej analizy omawianych przedstawień ikonograficznych można doliczyć

80 D. Morris, P. Collett, P. Marsh, M.O'Shaughnessy, Gestures: their origins and distribution, Cape-London 1979; I.S. Kon., Historyczno-etnograficzne aspekty seksuologii [w:] Seksuologia kulturowa, red. K. Imieliński, Warszawa 1984, s. 147; zob. rozdział Rude gestures and rude postures [w:] A. Weir, J. Jerman., Images of lust: sexual carvings on medieval churches, London-New York 1999, s. 100-110.

81 L. Hansmann, Amulett und Talisman, Erscheinungsform und Geschichte, München 1977, s. 254-260.

82 D. Morris, Magia ciała, tłum. B. Ostrowska, Warszawa 1993, s. 103; W. Kopaliński, Stownik symboli, Łódź 2006, s. 126.

83 Obecnie przechowywany w Muzeum Narodowym w Krakowie, zob. M. Walicki, Krakowska legenda Jana Jałmużnika, Warszawa 1966, s. 5-7, 16 i nn., il. 17.

${ }_{84}$ Por. M. Gutowski, Komizm w polskiej sztuce, Warszawa 1973, s. 98; K. Zalewska-Lorkiewicz, Ksiażę ciemności. O średniowiecznych wyobrażeniach szatana, Warszawa 1995 s. 45; E. Kizik, O źródłach i metodzie..., s. 395-396.

85 Dobrzeniecki, il. 81 A2, 82 A2, 106 A2b, 127; Gadomski, t. 2, il. 16, (fragm. 298), 17, 150; A.S. Labuda, Malarstwo tablicowe..., il. 201; MGP, il. 377; MNW s. 125, 135, 
się w sumie 30 wysuniętych języków, z czego aż połowa pochodzi z miniatur ilustrujaccych Rozmyślania dominikańskie. Raz tylko informacja o tym geście pojawiła się w tekście źródła i dotyczyła pachołków Kajfasza: „I wywiesili języki sprośne na pana Jezusa, śmiejąc się"86. Szczególnie ciekawe wydaja się te gesty, które są pewnego rodzaju modyfikacja, połączeniem różnych gestów. Obelżywe znaczenie wytkniętego języka bywało dodatkowo wzmacniane poprzez przyłożenie do ust palca lub palców. Były dwie opcje, albo dotykano palcem czubek języka ${ }^{87}$, albo wkładano palec w usta przy jednocześnie wytkniętym języku ${ }^{88}$.

Gest palca włożonego w usta sam w sobie był już traktowany jako zniewaga. Biorąc pod uwagę falliczną symbolikę palców, należałoby ten gest odbierać jako wyjątkowo obsceniczny. Intuicja podpowiada jednak, że jego obraźliwy charakter może być kojarzony z zachowaniem, o którym była mowa już wcześniej, mianowicie $\mathrm{z}$ wymiotowaniem. Wkładanie palców w usta jest skutecznym sposobem wywoływania zwrotu treści żołądkowej ${ }^{89}$, a naśladowanie tej czynności jest współcześnie czytelnym wyrażeniem swojej niechęci. Być może ten gest właśnie w tym symbolicznym znaczeniu funkcjonował już w średniowieczu ${ }^{90}$. Niezależnie od genezy był używany dla ubliżenia drugiej osobie, co poświadczaja przykłady źródłowe ${ }^{91}$. Wśród tych trzeba wspomnieć najwcześniejszą znaną w ślaskim malarstwie tablicowym redakcję tematu Ecce Homo, kwaterę poliptyku legnickiego powstałego w 1466 r. w pracowni Mikołaja Obilmana (ryc. 2). $\mathrm{Na}$ obrazie zwraca uwagę postać ubranego w obcisłe białe spodnie i czerwonobiałą tunikę szydercy, który przyklęka na prawym kolanie i patrzy w stronę Chrystusa ukazywanego przez Piłata. Mężczyzna

RD, s. 91, 99, 107, 111, 113, 183, 185, 187, 191, 193, 201; Sztuka na Ślqsku XII-XVI w...., il. 119a.

86 RD, s. 107.

87 KZSWP, t. 4, cz. I, il. 378.

88 Dobrzeniecki, il. 127; MNW, s. 135.

89 Znane sa średniowieczne przedstawienia ikonograficzne, na których wymioty prowokowane sa palcem. Np. miniatura zdobiąca angielski Psałterz z Xiii w., zob. https://www.pinterest.com/pin/309904018084486972/ [dostęp 8.05.2017].

90 Należy mieć jednak na uwadze, że gest ten był symbolicznie wieloznaczny, palec w ustach oznaczał także mądrość. Gest ten w znaczeniu nieobelżywym znajdujemy m.in. w scenach Matki Boskiej z dzieciątkiem, gdzie mały Jezus jest przedstawiony z palcem lub z palcami w ustach, zob. np. Gadomski, t. 1, il. 203; MGP, il. 1345; A. de Vries, Dictionary..., s. 185.

91 Ikonografia: Dobrzeniecki, il. 69 C2; Z. Kliś, Pasja..., s. 501; RD, s. 159, 181; MGP, il. 244 (ok. 1510). 
wykonuje jednocześnie dwa znaczeniowo tożsame gesty: palec wskazujący lewej ręki ma w ustach, zaś prawą pokazuje gest figi ${ }^{92}$. Nie ma wątpliwości, że pozycja, jaką przyjął, jest ostentacyjnym drwieniem z Jezusa.

Wśród obscenicznych gestów, które pojawiają się w sztuce średniowiecznej, jeszcze jeden wymagał włożenia palców w usta. Polegał on na chwyceniu warg dłońmi i jak najmocniejszym ich rozciagnięciu. W rzeźbie architektonicznej średniowiecza można znaleźć wyobrażenia głów lub masek diabelskich z rozwartymi w ten sposób ustami. Przedstawienia takie występuja bardzo licznie w całej europejskiej sztuce średniowiecznej, także w Polsce ${ }^{93}$. Ten osobliwy grymas pojawił się na gdańskim obrazie przedstawiającym Koronowanie cierniem (ok. 1500) ${ }^{94}$, gdzie jeden z drwiących z Chrystusa pachołków dotyka palcami swoich otwartych ust. Pośrednim świadectwem tego gestu może być też siedemnastowieczny obraz będący kopią malowidła z 1497 r., na którym jeden z szyderców nachyla się nad Chrystusem, eksponując szeroko rozwarte dłońmi usta ${ }^{95}$. Dość zagadkowe i trudne w interpretacji ze względu na nienajlepszy stan zachowania jest malowidło ścienne z początku XVI w. z Grębienia ${ }^{96}$. Przedstawiona jest tam pokaźnych rozmiarów postać stojąca na rozstawionych nogach, w przewiązanej w pasie, sięgającej do kolan sukmanie i kapturze $\mathrm{z}$ oślimi uszami ${ }^{97}$. Uniesionymi na wysokość szeroko rozwartych ust dłońmi dotyka nakrycia głowy, ewentualnie palcami wskazuje na twarz. Nie ma do końca pewności, kogo przedstawia to malowidło. Zdzisław Kliś przypuszczał, że może być to wizerunek

92 MNW, s. 106; Dobrzeniecki, il. 69 C2; J. Witkowski, Gotycki ołtarz główny kościoła Świętych Piotra i Pawła w Legnicy, Legnica 1997, il. XIII.

93 M. Gutowski, Komizm w polskiej sztuce..., s. 111-113; A. Karłowska-Kamzowa, Gotyckie malarstwo ścienne na Ślasku, „Rocznik Sztuki Ślaskiej” 1965, t. 3, s. 81; T. Jurkowlaniec, Gotycka rzeźba architektoniczna w Prusach, Wrocław 1989, il. 118, 377.

94 Kościół Mariacki, kwatera w predelli ołtarza św. Marcina; A.S. Labuda, Malarstwo tablicowe w Gdańsku w 2 pot. XV w., Warszawa 1979, il. 214; KZSWP, t. 8, cz. 1, il. 618 .

$95 \quad$ KZSWP, t. 4, cz. III, 2, il. 325.

96 Z. Kliś, Pasja..., il. 73 i.

97 Motyw przyprawiania oślich uszu pojawiał się dość często w średniowiecznej sztuce. Kaptury takie były atrybutem błaznów, czyli przedstawicieli zepsucia i rozpusty, M. Gutowski, Komizm postaci błazna w polskiej sztuce gotyckiej [w:] Treści dzieła sztuki, Warszawa 1969, s. 52, 62; M. Wilska, Strój błazna dworskiego u schytku średniowiecza [w:] Biedni i bogaci. Studia z dziejów społeczeństwa i kultury ofiarowane Bronisławowi Geremkowi w sześćdziesiata rocznicę urodzin, red. M. Aymard, Warszawa 1992, s. 316-317. 
Judasza ${ }^{98}$, wydaje się jednak bardziej prawdopodobne, że to prześmiewca, którego obecność jest komentarzem do wcześniejszej sceny, tj. sądu Piłata ${ }^{99}$.

Wspomniany już znak figi ${ }^{100}$ polegał na demonstracyjnym wystawieniu zaciśniętej pięści z kciukiem wystającym spomiędzy wskazującego i środkowego palca ${ }^{101}$. Według Stownika Staropolskiego „figi podawać" to: szydzić, uragać gestami rąk z charakterystycznym złożeniem palców, illudere alicui pollice impugno arte propria composito $^{102}$. Gest ten, znany już w starożytności, przybył do Polski najprawdopodobniej zza zachodniej granicy, gdzie informacje o nim pojawiaja się już w XII w. ${ }^{103}$ Jedno z wcześniejszych ${ }^{104}$ przedstawień gestu figi na terenie Polski znalazło się w zdobionym przez Jana z Żytawy mszale (ok. 1420), pochodzącym ze Ślaska (ryc. 3). Na miniaturze będącej ilustracją ukrzyżowania Chrystusa jeden z rzymskich żołnierzy stojących pod krzyżem ma wyciągniętą wysoko w górę rękę z dłonią ułożona we wspomnianym geście. Wydaje się jednak, że w zamyśle autora

98 Z. Kliś, Pasja..., s. 376.

99 Taka sytuacja została przedstawiona na poliptyku augustiańskim z 1468 r., w scenie sądu Piłata umieszczono postać błazna bijącego w bębenek, odzianego w przepasaną kurtkę i kaptur z czubem i uszami, zob. M. Gutowski, Komizm postaci..., s. 57, idem, Komizm w polskiej sztuce, s. 46-47, il. 4; s. 57; M. Wilska, Strój błazna..., s. $314-315$.

100 Informacje na temat gestu „figi” znaleźć można w literaturze dotyczącej antropologii kultury oraz etnografii. Trzeba jednak podchodzić do nich z dystansem, zwłaszcza gdy są poruszane tam kwestie historyczne, zdarzają się bowiem poważne błędy. Na przykład jest powielana fałszywa informacja, jakoby omawiany gest był znany w Polsce dopiero od XVII w.! Zob. Nowa księga przystów i wyrażeń przystowiowych polskich w oparciu o dzieło Samuela Adalberga, oprac. zespół pod kierunkiem J. Krzyżanowskiego, t. 1, Warszawa 1969, s. 563; J. Olędzki, Gesty nadziei. Gest Kozakiewicza, zacieranie rak, figa, „Polska Sztuka Ludowa - Konteksty” 1991, t. 55, nr 1, s. 42, 46.

101 Zob. Studium trzech rak (1493-1494) [w:] Albrecht Dürer - Rysunki, oprac. L. Hlaváček, przeł. E. Madany, Warszawa 1984, il. 6.

102 Stownik Staropolski, t. 2: D-H, red. S. Urbańczyk, Warszawa-Wrocław 1956-1959, s. 358. W Słowniku XVI-wiecznym podano jedynie znaczenie botaniczne i symbolikę biblijną. Znaczenie gestu było różne w zależności od regionu świata, w krajach śródziemnomorskich często też w zachodniej Europie pełnił funkcje apotropeiczne - chronił przed „złym spojrzeniem” oraz złośliwymi demonami i czarownicami, stąd też częste wykorzystanie tego znaku jako amuletu, zob. L. Hansmann, Amulett und Talisman..., s. 258.

103 N. Schnitzler, „Unformliche zeichen' und ,freche Ungebarden”..., s. 17-21.

104 Najprawdopodobniej gest figi jest także przedstawiony na obrazie Koronowanie cierniem (1370), z kwadryptyku wrocławskiego ze scenami z życia Jezusa i Marii. Nie jest on jednak na tyle wyraźny, by nie budził żadnych wątpliwości. (Wcześniej klasztor Klarysek we Wrocławiu, ob. Muzeum Narodowe w Warszawie), zob. MNW, s. 90. 
zachowanie to miało być raczej demonstracją szyderstwa przed tłumem zebranych niż chęcią urażenia Jezusa, gdyż Rzymianin spogląda w stronę płaczacych (m.in. Marii), a nie Ukrzyżowanego ${ }^{105}$. Na omówionym już obrazie legnickim Ecce homo (ryc. 2) mężczyzna pokazujący „figę” przyklękał. Połączenie przyklękania, które jest przecież wyrazem szacunku i uległości, ze zniewagą nabrało charakteru szczególnego szyderstwa i zostało wykorzystane niemal we wszystkich przedstawieniach, w których pojawia się gest figi. A ten znajdujemy przede wszystkim w scenach Koronowania cierniem ${ }^{106}$ i Ukazania Chrystusa przez Piłata ${ }^{107}$. Przykładem pierwszej ze scen niech będzie krakowski obraz Mikołaja Haberschracka z 1468 r., gdzie drwiący w ten sposób przyklękający oprawca, by obrazę uczynić jeszcze znaczniejsza, podpiera się w biodrze i pluje w stronę Koronowanego ${ }^{108}$. Na późniejszym, pochodzaccym z początku XVI w., przedstawieniu tego tematu szyderca nie tylko pokazuje „figę” i przyklęka, ale jeszcze dotyka ręką pośladków i wytyka język ${ }^{109}$. Na dwóch, powstałych niemalże w tym samym czasie, obrazach tablicowych ilustrujacych Ukazanie Chrystusa (kwatera Retabulum Złotej Marii ze Zgorzelca z 1511 r. ${ }^{110}$ i oleśnickie epitafium obrazowe Andrzeja Behra z 1513 r. $)^{111}$ pojawia się dodatkowy szyderczy

105 MGP, il. 895. Miniatura zaginęła podczas II wojny światowej. Podobnie przedstawiony gest figi znajdujemy w Czechach na nieco późniejszym obrazie (po 1430) o tej samej tematyce, zob. A, Matějček, Czech gothic painting, Praga 1950, il. 222, (ob. Galeria Narodowa w Pradze).

106 Chrystus w tłoczni mistycznej, Kraków (1440), na gest figi zwróciła uwagę H. Małkiewiczówna, zob. eadem, Interpretacja treści piętnastowiecznego malowidła ściennego $z$ Chrystusem $w$ tłoczni mistycznej w krużgankach franciszkańskich $w$ Krakowie, „Folia Historiae Artium” 1972, vol. 8, s. 75-76; Poliptyk augustiański Mikołaja Haberschracka, Kraków (ok. 1470); Gadomski, t. 2, 1460-1500, il. 74; Korona Marii, Wrocław (ok. 1500), ob. Muzeum Narodowe w Warszawie, Dobrzeniecki, il. 87 (27); MGP, il. 371; poliptyk z Kalisza (ok. 1510), MGP, il. 355; tryptyk ślaski, (1510-1520) ob. Muzeum Okręgowe w Toruniu, Dobrzeniecki, il. 106 A2 b.

107 Poliptyk legnicki Mikołaja Obilmana (1466), Dobrzeniecki, il. 69 C2; MNW, s. 106; tryptyk z Brzegu (1497) ob. Muzeum Okręgowe w Toruniu, Dobrzeniecki, il. 82 A2; Retabulum z Czerniny (1501), W. Marcinkowski, Gotycka nastawa ottarzowa u okresu rozwoju - Retabulum ze Ścinawy (1514) w kościele klasztornym w Mogilnie, Kraków 2006, il. 34, s. 31; Retabulum Złotej Marii ze Zgorzelca (1511), ibidem, il. 127, s. 79; epitafium Andrzeja Behra z Oleśnicy (ok. 1513), MGP, il. 377; obraz z Głogowa (ok. 1520), ob. Muzeum Sztuk Pięknych we Wrocławiu, Dobrzeniecki, il. 109 A.

108 Gadomski, t. 2, il. 74.

109 Dobrzeniecki, il. 106 A2 b.

110 W. Marcinkowski, Gotycka nastawa..., il. 127, s. 79.

111 MGP, il. 377; por. R. Kaczmarek, J. Witkowski, Ze studiów nad gotyckimi epitafiami obrazowymi mieszczaństwa na Ślasku [w:] Sztuka miast i mieszczaństwa XV-XVIII w. w Europie Środkowo-Wschodniej, red. J. Harasimowicz, Warszawa 1990. 
element-zdjęcie nakrycia głowy (por. ryc.2). Na każdym z tych przedstawień jeden z pachołków wyciaga w stronę Chrystusa dłoń zaciśniętą w geście figi i wytyka język, jednocześnie przyklęka, a w drugiej ręce trzyma zdjętą czapkę. Zestawienie wymienionych gestów nadało tym scenom znaczenia prześmiewczego hołdu. Podobne przedstawienia ikonograficzne, w których gest figi łączony był z innymi obraźliwymi zachowaniami, występowały w Europie Zachodniej ${ }^{112}$, także na terenach dzisiejszych Czech, Słowacji i Ukrainy ${ }^{113}$.

Warto jednak zwrócić uwagę na jeszcze jeden rodzimy obraz, tj. scenę biczowania z pentaptyku powstałego pod koniec XV w. we Wrocławiu ${ }^{114}$. Tu, w odróżnieniu od wyżej wymienionych przykładów, oprawca nie przyklęka, lecz stoi lekko pochylony w stronę związanego Chrystusa i wyciaga ku niemu prawą rękę w geście, który przypomina „figę". Kciuk jest schowany pod zgiętym palcem wskazujacym, tak jak to było w omówionych dotąd przypadkach, różnica jednak polega na tym, że wszystkie pozostałe palce skierowane są w stronę osoby znieważanej. Nie wydaje się, by tak wyszukany znak jak „figa” z wyprostowanymi palcami był improwizacją malarza, raczej odnosił się do realiów dnia codziennego, gdzie rozumiano jego obraźliwe znaczenie.

Wbrew wątpliwościom ${ }^{115}$ gest figi pojawił się także w źródle pisanym. W Rozmyślaniu przemyskim, w którym bardzo szczegółowo opisana jest męka Chrystusa i sposoby szydzenia z niego, znalazł się istotny dla tematu fragment: „niektórzy jego oczyma najświętrzyma z wielkim wołaniem figi podawali" ${ }^{116}$. Niestety, autor nie sprecyzował, cóż takiego wykrzykiwano, zapewne jednak miał na myśli obelgi. Nie sposób na podstawie tak krótkiej wzmianki mniemać, by istniała specjalna formuła słowna towarzysząca temu gestowi, ale nie można też tego wykluczyć. W Sprawie chędogiej pojawia się lakoniczna informacja o tym, że niektórzy wykonywali w kierunku Chrystusa obraźliwe

112 N. Schnitzler, „Unformliche zeichen' und ,freche Ungebarden”..., s. 13-42, il. 2-6; J.C. Schmidt, Gest..., s. 273-274; J.H. Marrow, Passion iconography, il. 20; idem, Inventing the Passions in the late Middle Ages [w:] The Passion Story from visual representation to social drama, ed. M. Kupf, Pennsylvania 2008, il. 26, 27.

113 A. Gronek, Ikony męki pańskiej. O przemianach w malarstwie cerkiewnym ukraińsko polskiego pogranicza, Kraków 2007, il. 134, 137.

114 Dobrzeniecki, 85 A2 b.

115 Edmund Kizik, który zwrócił uwagę na gest figi w gotyckim malarstwie tablicowym, dodał, że podobnych przykładów „na próżno by szukać w źródłach pisanych”, zob. E. Kizik, $O$ źródtach i metodzie..., s. 466.

$116 \mathrm{RP}, 652$. 
gesty, głośno przy tym wołając ${ }^{117}$. Podobieństwo kontekstów pozwala przypuszczać, że wśród bliżej nieokreślonych ruchów rąk mieścił się także gest figi ${ }^{118}$.

Obraźliwym gestem tożsamym znaczeniowo z „figa” było pokazywanie bądź dotykanie swojego nosa ${ }^{119}$. Na miniaturze przedstawiajaccej Chrystusa koronowanego cierniem przez dwóch oprawców w lewym dolnym rogu znalazła się postać trzy razy mniejsza od pozostałych, która palcem wskazującym lewej ręki dotyka czubka nosa, natomiast drugą dłonią wskazuje na Jezusa ${ }^{120}$. Autor miniatury, Jan z Żytawy, przedstawił tę scenę w sposób bardzo statyczny, brak w niej ekspresji. Nie zostały ukazane też żadne emocje, twarze pachołków zwrócone są w kierunku Jezusa i wydają się obojętne. O tym, że gest ten możemy interpretować jako iście błazeński, a tym samym prześmiewczy, świadczy pojawienie się podobnego gestu w Breviarium Biblioteki Jagiellońskiej powstałym w środowisku krakowskim około 1400 r. ${ }^{121}$ Wykonuje go głupiec, który umieszczony jest wewnątrz inicjału D[ixit insipiens] na karcie 23v. Stoi z lewą nogą wysuniętą do przodu, lewą ręką wskazuje na nos, a prawą przyciska do siebie sękaty kij. Jest bosy, w luźnym sięgającym do kolan, ściągniętym w pasie płaszczu z kapturem, głowę z rozwianymi włosami ma zwrócona profilem, rysy twarzy sa przesadne. Jak określił to Maciej Gutowski: „wygląda jak tępawy, wiejski głuptak”122. Zdecydowanie subtelniejsze, ale z pewnością niepozbawione negatywnej konotacji, jest zachowanie przedstawionej na kwaterze poliptyku legnickiego (1466) postaci, która środkowym palcem dotyka bocznej powierzchni nosa (ryc. 2) ${ }^{123}$. Umieszczenie jej w grupie uragających i domagających

117 „Nyektorzy iego naswietleyssymy oczima zwielgym wolanym sprosnoscz y podrzesnyenye sswyma rekoma vkazowaly", SCh, s. 47.

118 Tego zdania jest również E. Woźnik, Ofiary i krzywdziciele. Studium postaci w przedtrydenckim piśmiennictwie pasyjnym. Analiza językoznawcza, Łódź 2007, s. 230.

119 W słownikach symboli tłumaczone jako przedłużenie fallicznego nosa, aroganckie wyzwanie, zniewaga, zob. M. Oesterriecher-Mollowo, Leksykon symboli, s. 105; A. de Vries, Dictionary..., s. 185.

120 Brewiarz R 166 (ok. 1420); A. Karłowska-Kamzowa, Malarstwo ślaskie 1250 - 1450, Wrocław 1979, il. 74; MGP, il. 894.

121 Rękopis (1225); Z. Ameisenowa, Rękopisy i pierwodruki iluminowane Biblioteki Jagiellońskiej, Kraków 1958, s. 114, il. 48.

122 M. Gutowski, Komizm postaci..., s. 62. To określenie powtórzyli później M. Słowiński, Błazen. Dzieje postaci i motywu, Warszawa 1993.s. 153 oraz W. Dudzik, Karnawaty $w$ kulturze, Warszawa 2005, s. 57.

${ }_{123}$ MNW, s. 106; Dobrzeniecki, il. 69 C2; J. Witkowski, Gotycki ottarz główny kościoła Świętych Piotra i Pawła w Legnicy, Legnica 1997, il. XIII. 
się wykonania wyroku Żydów świadczy o tym, że gest ten bynajmniej nie był okazaniem życzliwości.

Nieco inny gest, nazywany „długim nosem” 124 albo - tak jak w Polsce - „graniem na nosie” 125 , nie pojawiał się często w europejskiej sztuce średniowiecznej. Warto zaznaczyć, że w literaturze tematu to właśnie omówiona wyżej, ślaska scena Koronowania cierniem z sygnatura „Johannes de Zittawia” jest podawana jako przykład tego obraźliwego gestu ${ }^{126}$. Jedno z wcześniejszych przedstawień „die lange Nase" z użyciem dwóch dłoni znajduje się w pochodzącej z X w., zdobiącej kodeks z Sankt Gallen, miniaturze, która wyobrażała wyszydzanie przez Żydów św. Pawła ${ }^{127}$. Jednak gest ten w takiej formie stał się popularny dopiero w czasach renesansu ${ }^{128}$.

Z pokazywaniem na nos, tym razem innej osoby, kojarzy się gest przedstawiony na jednej z miniatur Rozmyślań dominikańskich. Tam oprawca stoi naprzeciw omdlałego, podwieszonego na kolumnie Chrystusa i z bliskiej odległości wskazuje na niego palcem ${ }^{129}$. W tekście źródła to zachowanie nie jest wytłumaczone, a nad ilustracją widnieje jedynie krótki komentarz: „Iezvfz omdlaly obwyznąl naflvpye” ${ }^{130}$. Być może wyjaśnieniem jest wzmianka z Kroniki Kosmasa (XII w.) dotycząca sprzeczki dwóch zamożnych obywateli, którzy w złości szarpali paznokciami swoje gęste brody, a ponad to „szpetnie zawstydzali się wzajemnie obelżywymi łajaniami i przytykaniem palcem pod nosem" ${ }^{131}$. Pojawia się tu lekceważący gest przytykania palca pod

124 We Francji „Le nez long”, ale także „Pied de nez” (głupi nos); we Włoszech „Naso lungo” (długi nos), „Tanto di naso” (aż tak długi nos) „Marameo” albo „Palmo di naso” (dłoń nosa), w Niemczech „Die lange nase” (długi nos), zob. D. Morris i in., Gestures..., s. 35.

125 Także w Jugosławii - „Sviri ti spode” (grać na flecie), w Portugalii - „Tocar tromfete" (granie na trąbce), zob. ibidem, s. 35.

126 L. Kriss-Rettenbeck, Probleme der volkskundlichen Gebärdenforschung, „Bayerisches Jahrbuch für Volkskunde“ 1964/65, s. 35; L. Hansmann, Amulett und Talisman..., s. 525, il. 666; M.S. Kirch, Deutsche Gebärdensprache, Hamburg 1995, s. 37-38.

127 St. Gallen codex 64, fol. 12, przechowywany w Stiftsbibliothek St. Gallen w Szwajcarii, zob. G. Kocher, Zeichen und symbole des Rechts. Eine historische ikonographie, Münschen 1992, s. 17, il. 6.

${ }_{128}$ Przykładem może być grafika Pietra Bruegela (starszego) Święto Gtupców z 1560 r., por. D. Morris i in., Gestures..., s. 29.

129 RD, il. LXIX, s. 56.

130 RD, s. 56.

131 Kosmasa Kronika Czechów, I. 4, oprac. M. Wojciechowska, Warszawa 2006, s. 91-92. O geście tym jako akcie zniewagi pisał też J. Dowiat, Środki przekazywania myśli [w:] Kultura Polski średniowiecznej X-XIII w., red. J. Dowiat, Warszawa 1985, s. 213. 
nos. W prawdzie informacja o nim pochodzi ze źródła czeskiego, ale słowiański język gestów jest dość jednolity, możemy zatem przypuszczać, że tego rodzaju gestykulacji używano także w Polsce ${ }^{132}$. Byłby to już kolejny przykład, po wysiąkaniu nosa i dotykaniu własnego nosa, w którym zniewaga wiążę się z tą częścią ludzkiego ciała ${ }^{133}$. Nie można wykluczyć takiej możliwości, niemniej jednak przedstawiony gest bardziej kojarzy się z wytykaniem palcami niż z ubliżającym drażnieniem.

Wytykanie palcem było gestycznym odpowiednikiem słownego naigrywania się. Wskazywana osoba znajdowała się wtedy w centrum uwagi i była narażona na śmieszność, co uwłaczało jej godności. Ten sposób piętnowania można znaleźć już w Starym Testamencie, gdzie Izajasz „szydercze pokazywanie palcem” nazywał niegodnym zachowaniem (Iz 58, 9) ${ }^{134}$. Gest ten w średniowiecznej ikonografii najczęściej występuje w scenie Ukrzyżowania (np. ryc. 3) ${ }^{135}$, tu jednak jest konieczna ostrożność w wyciaganiu wniosków, gdyż prawdopodobnie jest to ilustracja do słów, jakie według św. Mateusza miał wypowiedzieć setnik po śmierci Chrystusa: „Prawdziwie, Ten był Synem Bożym" (Mt, 27, 54). Niemniej, postacie wytykające palcem pojawiają się także w innych scenach, w których ewidentnie drwiono z Chrystusa (np. ryc. 1 i 4) ${ }^{136}$. Negatywną konotację gestu potwierdza téz fakt, że dłoń z wystawionym palcem wskazującym była także przedstawiana jako jeden z elementów Narzędzi Męki Pańskiej ${ }^{137}$. Wydaje się, że wytykanie palcem miało także wzmocnić wymowę obraźliwej gestykulacji. Przemawiają za tym przykłady przedstawień ikonograficznych,

132 Do dziś funkcjonuje związek frazeologiczny „dać komuś prztyczka w nos”, czyli ośmieszyć kogoś, okazać komuś lekceważenie, zob. Stownik frazeologiczny, red. W. Głuch, Kraków 2003, s. 124.

${ }_{133}$ Warty odnotowania jest jeszcze jeden obsceniczny gest, który jednak nie służył znieważaniu, a był raczej niedwuznaczną propozycją. Polegał na przyłożeniu dłoni do twarzy w taki sposób, by nos znalazł się między palcami, zob. herb kaletników, k. 302 (1505-1512), J. Podlecki, Miniatury z Kodeksu Baltazara Behema, Kraków 2000.

134 Gest ten ma także swoje odzwierciedlenie w frazeologii, zwrot „wytykać palcem/palcami” oznacza zniesławienie, publiczną krytykę, zob. Stownik frazeologiczny języka polskiego, A-P, red. S. Skorupka, Warszawa 1974, s. 637; Słownik frazeologiczny w układzie tematycznym i alfabetycznym, red. W. Głuch, Kraków 2003, s. 128.

135 Zob. np. MGP, il. 66, 115, 315, 407, 895, 899, 920.

136 MGP, il. 244, 463, 806; RD, s. 89, 91, 99, 125, 133, 143, 159, 169, 193, 203. Obraźliwy gest wytykania palcem pojawia się także w kontekście obrażania Matki Boskiej, zob. RD, s. 181; oraz drwienie ze św. Bartłomieja, zob. MGP, il. 438.

137 Np. MGP, il. 96, 291 (też Gadomski, t. 1, il. 114); Gadomski, t. 1, il. 113, 115; Dobrzeniecki, il. 24 A2 b 
na których oprawcy pokazują na Chrystusa, wykonując jednocześnie inny gest, na przykład wytykająjęzyk, wkładaja palce do ust, pokazują na nos lub wystawiaja wyprostowaną dłoń. Takie połączenie nie pozostawiało wątpliwości, kogo dotyczy zniewaga.

Znakiem niechęci przedstawianym w scenach pasyjnych było również skrzyżowanie palców ${ }^{138}$. Gest taki zilustrował Mistrz Ołtarza z Warty w scenie Ecce homo (1520), której kompozycja jest niemal dosłownie przejęta z drzeworytu Hansa Schäufeleina (1507) ${ }^{139}$. Także autor miniatur Rozmyślań dominikańskich przypisał takie gesty tłumowi zebranemu pod pałacem Piłata w czasie Ukazania (ryc. 4) ${ }^{140}$. To samo znaczenie miało skrzyżowanie uniesionych wysoko rak. Ten rodzaj gestykulacji widzimy na poliptyku legnickim (1466) w scenie Ukrzyżowania ${ }^{141}$ oraz na pochodzacym z Pruszcza Gdańskiego, datowanym na początek XVI w., przedstawieniu Ecce homo ${ }^{142}$.

Nie używano w średniowiecznej Polsce jednego z najstarszych obscenicznych gestów, tj. wystawionego środkowego palca ${ }^{143}$. Potwierdzaja to negatywna kwerenda oraz przykłady, w których taki układ dłoni pojawia się, jednak w znaczeniu nieobelżywym ${ }^{144}$. Wydaje się natomiast, że nieprzyzwoitą wymowę przypisywano kciukowi ${ }^{145}$. W scenie Ukazania legnickiego ołtarza (1466), gdy Poncjusz Piłat zwraca się do zebranych z pytaniem, co uczynić z Chrystusem, jeden z Żydów wskazuje palcem na wystawiony do góry kciuk swojej lewej ręki i patrzy na Jezusa, inni w tym czasie wykonują obelżywe

138 Wspomniane przez J.C. Schmidt, Gest..., s. 273.

139 Dobrzeniecki, il. 24 A2b; także u Baltazara Opecia, zob. ŻWSB, s. LXXXIX.

140 RD, s. 169. Również w scenie wcześniejszej RD, s. 133.

141 MNW, s. 107.

142 Dobrzeniecki, il. 132 C1.

143 Gestu używano już w starożytnym Rzymie, gdzie był tak powszechny, że środkowy palec nazywano tam „palcem nieprzyzwoitym” (digitus infamis) albo „palcem haniebnym" (digitus impudicus), zob. W. Kopaliński, Stownik symboli..., s. 297; także C. Sittl, Die Gebärden der Griechen und Römer, Leipzig 1890.

144 W średniowieczu środkowy palec przypisany był Chrystusowi i symbolizował zbawienie, zob. np. B. Midońska, Małopolskie malarstwo ksiażkowe 1320-1540, Warszawa 1993, il. 56; Gadomski, t. 2, il. 74; KZSWP, t. 11, z. 18, fig. 173.

145 W starożytnym Rzymie, podczas walk gladiatorów, podniesienie wyprostowanego kciuka w górę i być może kręcenie nim (pollice verso) oznaczało - inaczej niż się zwykle mniema - żądanie dobicia rannego gladiatora, zob. W. Kopaliński, Stownik symboli..., s. 296; A. Corbeill, Thumbs in Ancient Rome: Pollex as Index, „Memoirs of the American Academy in Rome" 1997, vol. 42, s. 1-21; idem, Nature Embodied. Gesture in Ancient Rome, Princeton 2004, s. i 62 nn. Przeciwny gest, czyli schowanie kciuka w dłoni, oznaczał darowanie życia, a w średniowieczu był magicznym znakiem ochrony i pomyślności, zob. ibiem, s. 46. 
gesty (ryc. 2.) ${ }^{146}$. W tej samej scenie, przedstawionej przez malarza wrocławskiego zwanego Mistrzem Pasji z Góry Śląskiej (1513), stojacy wśród gapiów arcykapłan wystawia do góry kciuk zaciśniętej lewej dłoni i spogląda za siebie ${ }^{147}$. Być może jest to interpretacja fragmentu Ewangelii św. Marka, w którym mowa o podburzaniu tłumu przez kapłanów (Mk 15, 11-15), wówczas gest byłby zachętą do opowiedzenia się przeciw Chrystusowi. Watpliwości co do obraźliwego znaczenia gestykulacji nie ma w przypadku ryciny wyobrażającej Naigrywanie się, która zdobi dzieło Baltazara Opeca. Tam jeden z ciemiężycieli patrzy na Chrystusa i kieruje w jego stronę prawą dłoń z wystawionym kciukiem, zaś palcem wskazującym lewej ręki pokazuje wykonywany przez siebie gest. Podobny układ dłoni widzimy u klęczącego obok szydercy, który dodatkowo parodiuje okazywanie szacunku przez zdjęcie nakrycia głowy. O tym, że przedstawieni Żydzi drwią z Chrystusa, świadczy także mimika twarzy, gdyż szeroko się uśmiechają ${ }^{148}$.

Warto wspomnieć o ciekawym geście, który polegał na dociśnięciu kciuka do policzka i skierowaniu palca wskazującego tej samej dłoni w stronę osoby znieważanej. Przykład takiego połączenia mamy na rewersie Poliptyku kuśnierzy wrocławskich (1497), gdzie została przedstawiona scena Ukazania. Tam jeden z zebranych mężczyzn, będący najbliżej Chrystusa, szyderczo przyklęka przed Nim i zdejmuje kapelusz, a jednocześnie wytyka język i wykonuje opisany - z cała pewnością obraźliwy - gest ${ }^{149}$.

Analiza średniowiecznej ikonografii pozwala na dodanie do katalogu obelżywych zachowań jeszcze jednego gestu, który współcześnie nie jest czytelny. Mowa o wyprostowanej dłoni skierowanej w stronę znieważanej osoby. Gest ten był wyobrażany w scenach Ecce homo i nieznacznie różnił się w poszczególnych przedstawieniach. Na przykład na obrazie z Brzegu dłoń żołnierza ma lekko rozstawione palce ${ }^{150}$, inaczej to wygląda u Mistrza Ołtarza z Warty, gdzie postać wyrażająca gest ma wszystkie palce dociśnięte ${ }^{151}$. Niekiedy znak wyprostowanej dłoni łączono z wytykaniem palcem, jak

\footnotetext{
146 MNW, s. 106

147 MNW, s. 114.

148 ŻWSB, s. LXXVI.

149 Sztuka na Ślasku XII-XVI w...., s. 384-388, il. 119b rewers.

150 Dobrzeniecki, il. 82 A2. Podobnie wygląda to na wrocławskim obrazie z końca

151 Dobrzeniecki, il. 24 A2b.
} XV w., il. 85 B2b. 
na miniaturze Rozmyślań (ryc. 4) ${ }^{152}$.Częstotliwość, z jaką ów układ się pojawiał wśród innych obraźliwych zachowań, świadczy o tym, że nie był przypadkowy ${ }^{153}$. Gest przypomina podanie ręki podczas przywitania, ale zarówno kontekst sytuacyjny, jak i odległość między Chrystusem a postacia, która gest wykonuje, wykluczają taka możliwość. Trudno także przyjąć, by chodziło o uchwycenie momentu policzkowania, gdyż dłoń oprawcy jest zbyt nisko. Nieodparcie nasuwa się skojarzenie z opisanym wyżej gestem dłoni z wystawionym kciukiem, przypomina również odnotowany już gest „figi z rozprostowanymi palcami”. Podobieństwo formy oraz okoliczności, w których się pojawia, przemawiaja za negatywna wymowa tego znaku. Ponadto, biorąc pod uwagę obsceniczną symbolikę pojedynczego palca, można mniemać, że pięć palców skierowanych w stronę pogardzanej osoby powinno mieć to samo pejoratywne, a nadto wzmocnione znaczenie.

Problemów interpretacyjnych nie sprawiaja gesty, których obsceniczny charakter wiąże się ze wstydliwymi częściami ciała. Wypięcie pośladków w celu upokorzenia i zakpienia z osoby oglądającej nie stanowi specjalności omawianej epoki. Gest ten już w starożytności uchodził za obrazę ${ }^{154}$, tę rolę spełniał też w czasach nowożytnych ${ }^{155}$. $\mathrm{Z}$ oczywistych względów w sztuce podejmującej tematy religijne obowiązywały pewne ograniczenia odnośnie do tego, co można było pokazać, dlatego gest wypiętych pośladków był przedstawiany raczej w sposób skonwencjonalizowany, bez pokazywania nagości. Na kwaterze tryptyku pochodzącego ze Ślaska - Cierniem ukoronowanie (ok. 1510-1520) - jeden z pachołków, przyklękając na prawym kolanie, wytyka język, jedną ręką pokazuje „figę”, a drugą dotyka pośladków ${ }^{156}$. Odważniejsze przedstawienie, bo połączone już z częściowym obnażaniem, znalazło się w Rozmyślaniach dominikańskich, tam przyklękający przed Chrystusem mężczyzna wkłada rękę w swoje nisko zsunięte spodnie. Inny motyw pojawił się na toruńskim obrazie wyobrażającym

152 RD, s. 165, 169.

153 Gadomski, t. 1, il. 234; t. 2, il. 74 lub MGP, il. 291; Gadomski, t. 2, il. 17 lub MGP, t. 3, il. 465; Gadomski, t. 2, il. 151; Dobrzeniecki, il. 82 A2; 84 A2 a; 85 B2 b; MNW s. 135, (Dobrzeniecki, il. 127); MGP, il. 377; MNW, s. 114; Dobrzeniecki, il. 24 A2 b; 109 A; RD, s. 169; ŻWSB, s. 185, 192; por. J.H. Marrow, Passion iconography..., il. 13, 19.

154 Podczas oblężenia miast i grodów obnażanie pośladków było praktykowane przez obie walczące strony. Podobnie odbierano obnażanie sromu czy chłostanie po pośladkach, zob. T. Seweryn, Ikonografia etnograficzna, „Lud” 1947, t. 37, s. 661.

155 Gest ten jest dobrze udokumentowany w źródłach sądowych XVII i XVIII w., zob. T. Wiślicz, Gest obraźliwy..., s. 420-423.

156 Dobrzeniecki, il. 106 A2b. 
Biczowanie (1495), na którym pokorny, niemalże zrezygnowany Chrystus jest otoczony dynamicznymi postaciami oprawców. Jeden z nich, obrócony tyłem do widza, a bokiem do Jezusa, zamierza się, by uderzyć Go trzymanymi oburącz rózgami. Opuszczone niedbale spodnie siepacza odsłaniają jego tylnią część ciała, przysłoniętą nieco kusa, obcisłą bielizną ${ }^{157}$. Ta obsceniczna, wręcz groteskowa scena, nabiera tym większej wyrazistości, że została skontrastowana z osobą klęczącego niżej, pełnego powagi donatora ${ }^{158}$. W scenach Niesienia krzyża powtarza się motyw dziecka, które unosi tunikę w kierunku upadającego pod krzyżem Chrystusa. Na niektórych przedstawieniach dziecko ma podniesioną rękę i jest gotowe do rzutu kamieniem ${ }^{159}$, na innych widać, że to właśnie kamienie są w podwiniętej sukma$n^{160}$, ale zdarzają się także przypadki jak na obrazie Retabulum ze Ścinawy (1514), gdzie pozostał tylko sam gest zadarcia do góry stroju. Należy go zatem traktować jako obraźliwe obnażanie się ${ }^{161}$.

W ikonografii średniowiecznej z terenów Polski raz tylko pojawia się tzw. gest „rogów”. Znaleźć go można na wykonanej przez Jana z Żytawy miniaturze mszału ślasskiego przedstawiającej Ukrzyżowanie (1420) ${ }^{162}$.

157 Przedstawianie oprawców w wielokolorowych, kusych czy udziwnionych pod względem kroju strojach było typowym zabiegiem w sztuce średniowiecznej i służyło podkreśleniu różnicy między złymi postaciami a dobrymi, zob. M. Gutowski, Komizm w polskiej sztuce..., s. 234; Z. Żygulski, Średniowieczna zbroja szydercza, [w:] Sztuka i ideologia XV wieku. Materiaty Sympozjum Komitetu Nauk o Sztuce Polskiej Akademii Nauk, Warszawa 1-4 grudnia 1976, red. P. Skubiszewski, Warszawa 1978, s. 587-607; E. Kizik, Kolorowy ubiór kata. Przyczynek do ikonografii odzieży na przełomie XV i XVI w. [w:] Kaci, święci, templariusze, red. B. Śliwiński, Malbork 2008 („Studia z Dziejów Średniowiecza”, nr 14), s. 191-204; K. Kopania, Przedstawienia odrażajace..., s. 65-66, por. R. Mellinkoff, Outcasts: Signs of Otherness in Northern European Art of the Late Middle Ages, t. 1, Berkeley-Los Angeles-Oxford, 1993.

158 MGP, il. 803.

159 Np. skrzydło poliptyku z Sulechowa (1499), MGP, il. 347; tryptyk z Kościana (1507), KZSWP, t. 5, z. 10, il. 219; Retabulum ze Ścinawy (1514), W. Marcinkowski, Gotycka nastawa..., il. 141.

160 Retabulum Złotej Marii ze Zgorzelca (1511), W. Marcinkowski, Gotycka nastawa..., il. 140; ŻWSB, s. LXXXXIII. Przedstawienia wzorowane na rycinach Speculum passionis Ulricha Pindera z 1507 r., zdobionych przez H. Schäufelina, por. A.M. Olszewski, Pierwowzory graficzne późnogotyckiej sztuki małopolskiej, Wrocław 1975, s. 74-76; W. Marcinkowski, Gotycka nastawa..., il. 139.

161 Retabulum ze Ścinawy (1514), W. Marcinkowski, Gotycka nastawa..., il. 136, tu tė̇ raczej karzeł, a nie dziecko; por. J. Marrow, Circumdederunt me canes multi: Christ's Tormentors in Northern European Art of the Late Middle Ages and Early Renaissance, „The Art Bulletin” 1977, vol. 59, issue 2, s. 167-181; K. Kopania, Przedstawienia odrażajace, s. 66.

162 MGP, il. 895, por. przyp. 105. 
Tam, wśród tłumu zgromadzonego pod krzyżem, trzech żołnierzy wykonuje gesty w kierunku powieszonego już Chrystusa. Jeden wytyka Go palcem, drugi pokazuje „figę”, a trzeci ma wyciagniętą w górę zaciśsniętą dłoń z wystawionym kciukiem, palcem wskazującym i małym palcem (ryc. 3). Historia tego gestu - podobnie jak gestu „figi” - sięga czasów przedchrześcijańskich i ma genezę apotropeiczną ${ }^{163}$. W sztuce europejskiej pojawia się w dwóch odmianach: wertykalnej, wówczas wystawione palce skierowane są ku górze lub horyzontalnej z palcami ustawionymi prosto, w kierunku obrażanej czy zaklinanej postaci ${ }^{164}$.

Kolejnym gestem, który w swojej podstawowej formie pojawia się tylko raz w omawianej ikonografii, jest pokazywanie na skron. W pochodzącym z końca XIV w. obrazie ściennym zdobiącym kościół parafialny w Kałkowie Chrystus jest prowadzony przed oblicze Piłata przez czterech pachołków. Pierwszy z nich, rozpoczynający pochód, patrzy w stronę prefekta i pokazuje palcem wskazującym lewej ręki na swoją skroń. To samo robi postać zamykająca pochód $\mathrm{z}$ tyłu, ta jednak dodatkowo pokazuje palcem drugiej dłoni do przodu, najpewniej w stronę Chrystusa. Istotnym elementem jest strój błazeński, jaki ma na sobie, pozwala to na zinterpretowanie gestu jako prześmiewczego ${ }^{165}$. Tym razem obraźliwa gestykulacja nie ma charakteru obscenicznego, jest to raczej - analogicznie do współcześnie znanego gestu „pukania się w głowę” - odwołanie się do cech umysłowych, byłoby to zatem jednoznaczne z powiedzeniem osobie znieważanej, że jest głupia. Taką interpretację pozwalają przyjąć źródła pisane, według których Chrystus niejednokrotnie był obrażany słownie ${ }^{166}$. Na przykład w obecności Heroda pachołkowie biegali za Jezusem w koło, wołając: „,zalony Iezv, blazno Iezv, glvpi Iezv”, sam Herod też miał stwierdzić, że gardzi Jezusem „yako <n>yemądrym”, gdyż tylko głupiec nie odpowiada na pytania ${ }^{167}$.

163 Istnieje wiele teorii na temat pochodzenia i znaczenia gestu, funkcjonował jako znak ochronny przeciwko złu, ale mógł być także klątwą skierowana przeciw Bogu, czy obelga jednoznaczną z nazwaniem kogoś „rogaczem”. Jedno ze starszych przedstawień pochodzi z V w. p.n.e., zob. D. Morris i in., Gestures..., s. 120-134; L. Hansmann, Amulett und Talisman..., s. 259-260; G.A. Wainwright, The Earliest Use of the Mano Cornuta, „Folklore” 1961, vol. 72, no. 3, s. 492-495.

164 Ibidem.

165 MGP, il. 25; zob. tė̇ Kultura Polski średniowiecznej, red. B. Geremek, Warszawa 1997, s. 47, il. 67.

166 Np. RP, s. 788; RD, s. 122, 124.

167 RD, s. 124. 
Zastanawiający jest także gest, jaki wykonuje prześmiewca w grudziądzkim Koronowaniu cierniem (1390). Klęcząc przed siedzącym Chrystusem, śmieje się szyderczo i kciukiem oraz palcem wskazującym lewej ręki pokazuje na swoją twarz. Trudno orzec, czy pokazuje na skroń, czy na oko, być może chodzi o nos, który jest akurat na wysokości obu palców, niewątpliwie jednak ma to charakter obraźliwy ${ }^{168}$.

W kontekście wyśmiewania i obelg sugerujących ułomność intelektualna pojawił się w narracjach apokryficznych gest, o którym wspominają także Ewangelie, mianowicie potrząsanie głową ${ }^{169}$. Tak mieli się zachowywać oprawcy podczas koronowania cierniem: „kywayacz glowamy mowyly $\mathrm{O}$ glvpy czlowyczę"170, a także podczas ukrzyżowania: „A drvdzy chwyeyąc glowa wolaly wiecz ten chczal kofczol bozy <b>uzicz"171. Gest ten był na tyle czytelny, że używanie go podczas wypowiadania jakichś słów nadawało im charakter drwiny ${ }^{172}$.

Możliwość łączenia jednych gestów z innymi, wielość kombinacji ułożeń palców, dłoni, zmiana postawy ciała czy mimiki - wszystko to sprawiało, że średniowieczny repertuar niewerbalnych sposobów obrażania był bardzo bogaty. Należy przy tym pamiętać, że ikonografia, która dotrwała do naszych czasów, jest zaledwie częścią tego, co powstało w średniowieczu, zatem i przedstawienia obelżywych gestów prawdopodobnie nie stanowią całości.

Uzupełnieniem moga być dzieła malarskie powstałe w innych regionach Europy, zwłaszcza w krajach sasiednich. Wśród nowych motywów wymienić można gest naciągania dolnej powieki. Polegał on na przyłożeniu palca bądź palców do skóry pod okiem i pociagnięciu w dół dla uzyskania szpetnej deformacji. W taki sposób szydzi z Chrystusa jeden z pachołków na obrazie niemieckiego Mistrza Legendy Dominikańskiej. Gdy się przyjrzeć dokładnie, widać pod palcem wskazujacym wewnętrzną stronę dolnej powieki. Szyderstwo to zostało wzbogacone o gest kciuku włożonego w usta i połączone

168 Dobrzeniecki, il. 32 A4 (lub MNW, s. 92).

169 RD, s. 202; SCh, s. 92.

170 RD, s. 156.

171 RD, s. 202.

172 D. Kozaryn, Ksztalt stylistyczny..., s. 63-64; eadem, Stownictwo nazywajace agresywne zachowania słowne w staropolszczyźnie [w:] Życzliwość $i$ agresja w języku $i$ kulturze, red. A. Dąbrowska i A. Nowakowska, „Język a Kultura” 2005, t. 17, s. 301. 
z prześmiewczym przyklękaniem ${ }^{173}$. Drugi przykład pochodzi ze sceny Ukoronowania cierniem datowanej na $1480 \mathrm{r}$. Tam, w grupie oprawców, z których część jest zajęta nakładaniem Chrystusowi korony, a część drwieniem z Niego, znalazł się mężczyzna - stojąc naprzeciwko Jezusa, oburacz rozciaga sobie usta i wkłada w nie środkowe palce, wytyka język i palcami wskazującymi prawej i lewej dłoni naciąga skórę policzków ${ }^{174}$.

Wymienione wyżej obraźliwe gesty rzadko kiedy pojawiały się osobno, zwykle jest ich kilka na jednym przedstawieniu ikonograficznym ${ }^{175}$. Wspólne występowanie w tym samym kontekście potwierdza, że są tożsame znaczeniowo, co ułatwia interpretacje niepewnych znaków. Poza poniżającymi zachowaniami, jakie zostały opisane w Piśmie Świętym (opluwanie, policzkowanie, bicie, targanie za brodę, szydercze hołdy, przybranie w purpurę, koronowanie cierniem, gra w zgadywanie: kto uderzył, potrząsanie głowa), pojawiły się w omawianych źródłach gesty będące swoistym dodatkiem średniowiecznych autorów. Lista ich jest całkiem długa - wyciaganie za włosy, wytykanie języka, wkładanie palców w usta, rozwieranie ust dłońmi, gest figi, granie na nosie, wystawianie kciuków, gest wystawionej dłoni, wytykanie palcami, gest rogów, wskazywanie na skroń, pokazywanie pośladków - a to z pewnością nie wszystkie obraźliwe gesty, jakich używano. Najczęściej znajdujemy je w scenach wyobrażających Ukazanie Chrystusa (Ecce homo), także w Naigrywaniu, Koronowaniu cierniem i Biczowaniu, rzadziej w przedstawieniach Upadku pod krzyżem i Ukrzyżowania. Ciekawym zabiegiem było umieszczanie symboli ubliżających gestów na przedstawieniach Arma Christi. Przedstawiane przez autorów źródeł gesty musiały być zrozumiałe dla ówczesnych odbiorców, co oznacza, że wynikały z praktyki dnia codziennego i tym samym stanowią świadectwo ówczesnych sposobów znieważania. Ich znaczna liczba świadczy o rozbudowanym systemie komunikacji niewerbalnej, co zgadza się z dotychczasowymi badaniami tej sfery obyczajowości w wiekach średnich. Jednocześnie niniejsze rozważania uświadamiają ciagłą potrzebę studiów nad średniowieczną mentalnością.

173 L. Hansmann, Amulett und Talisman..., s. 326, il. 680.

174 Ibidem, il. 679.

175 W sztuce polskiej nie unikano drastycznych scen obrazy Chrystusa, w odróżnieniu od np. sztuki bizantyjskiej, gdzie moment męki niechętnie był ilustrowany, zob. A. Różycka-Bryzek, Bizantyjsko-ruskie malowidła z kaplicy zamku lubelskiego, Warszawa 1983, s. 77. 


\section{Abstract \\ Insulting Gestures in the Light of Polish Late-Medieval Written and Iconographic Sources on the Passion of Jesus}

In the Middle Ages insulting behaviours took various forms. The paper focuses on those ways of insulting which were expressed by gestures, at the same time emphasising that this is a research area that has not yet inspired a separate study. The paper analyses late-medieval apocryphal narratives and iconographic sources. The selection of sources was determined by the presence of the topic of the Passion of Jesus, in which the motif of insult was especially frequent. Due to this biblical motif, the first section of the paper discusses the instances of insulting Christ in the Holy Bible, which constitute a point of reference for a further discussion. It will enable us to point out those gestures which complemented the medieval canonical narrative. In sum, in the text we will find descriptions and interpretations of over 20 insulting behaviours, most of which are also illustrated by appropriate iconography. It has been noted that the gestures presented by the authors of the sources had to be understandable for the people of those times; they therefore had to be drawn from the practice of everyday life, and by that token constitute a testimony of the then ways of insulting. 


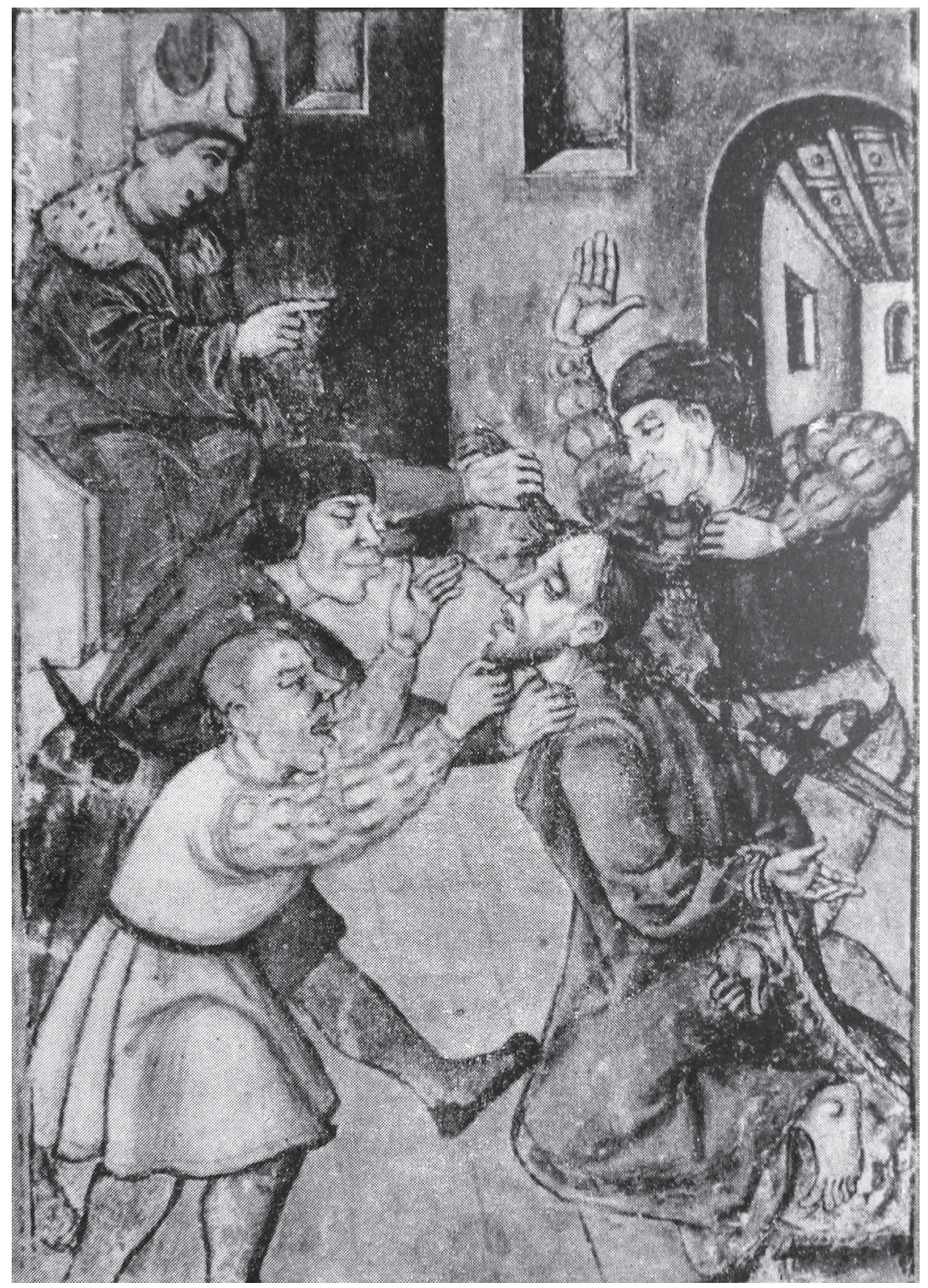

Ryc. 1. Chrystus przed Annaszem (frag.), Rozmyślania dominikańskie, 1532 r. [w:] Rozmyślania dominikańskie, t. 1, wyd. i oprac. K. Górski, W. Kuraszkiewicz, Z. Rozanow (oprac. ikonograficzne), Wrocław 1965, miniatura XLV 


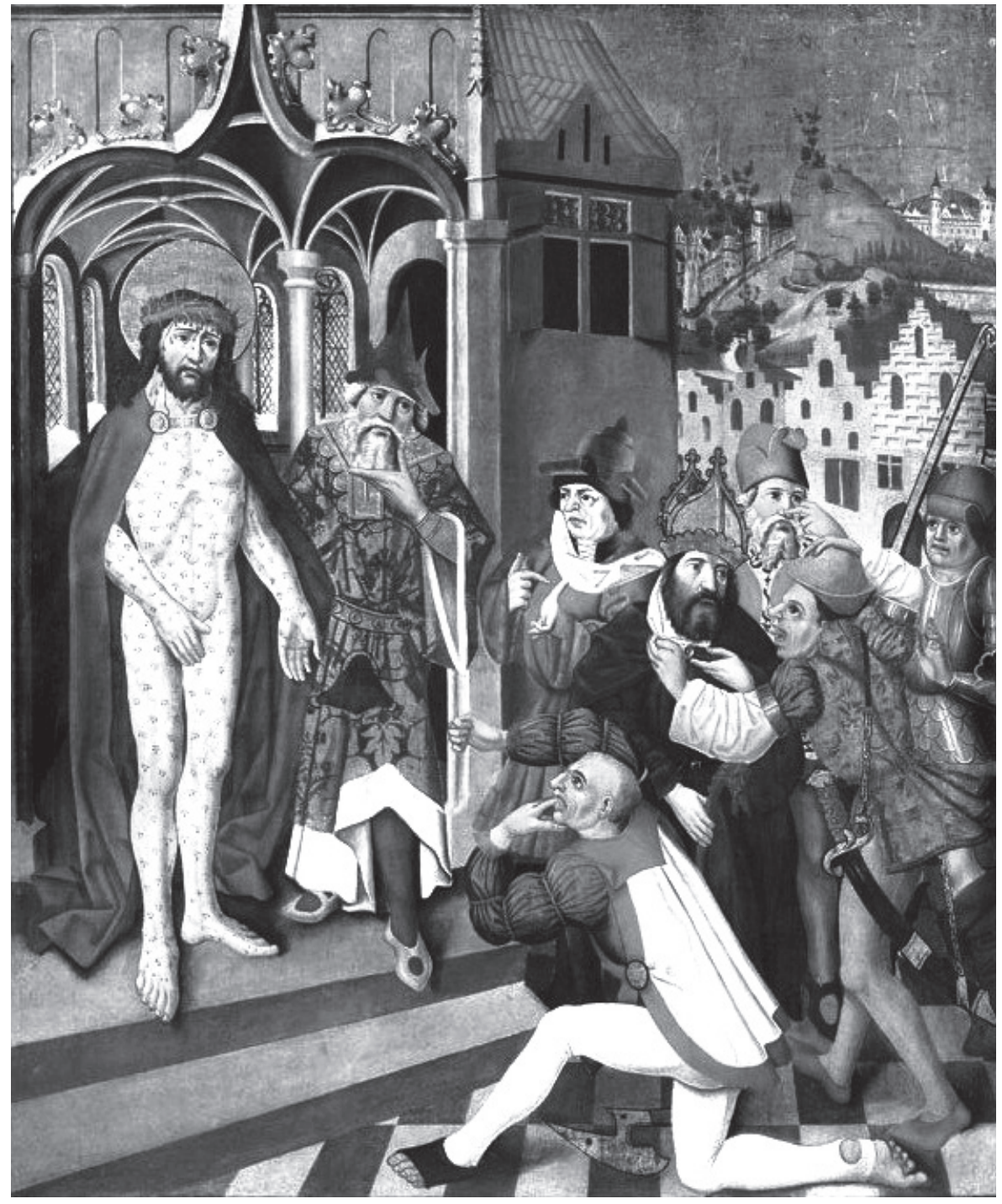

Ryc. 2. Ecce homo, Mikołaj Obilman, poliptyk legnicki, 1466 r. [w:] Muzeum Narodowe w Warszawie. Arcydzieła malarstwa, red. E. Folga-Januszewska, Warszawa 2005, s. 106 


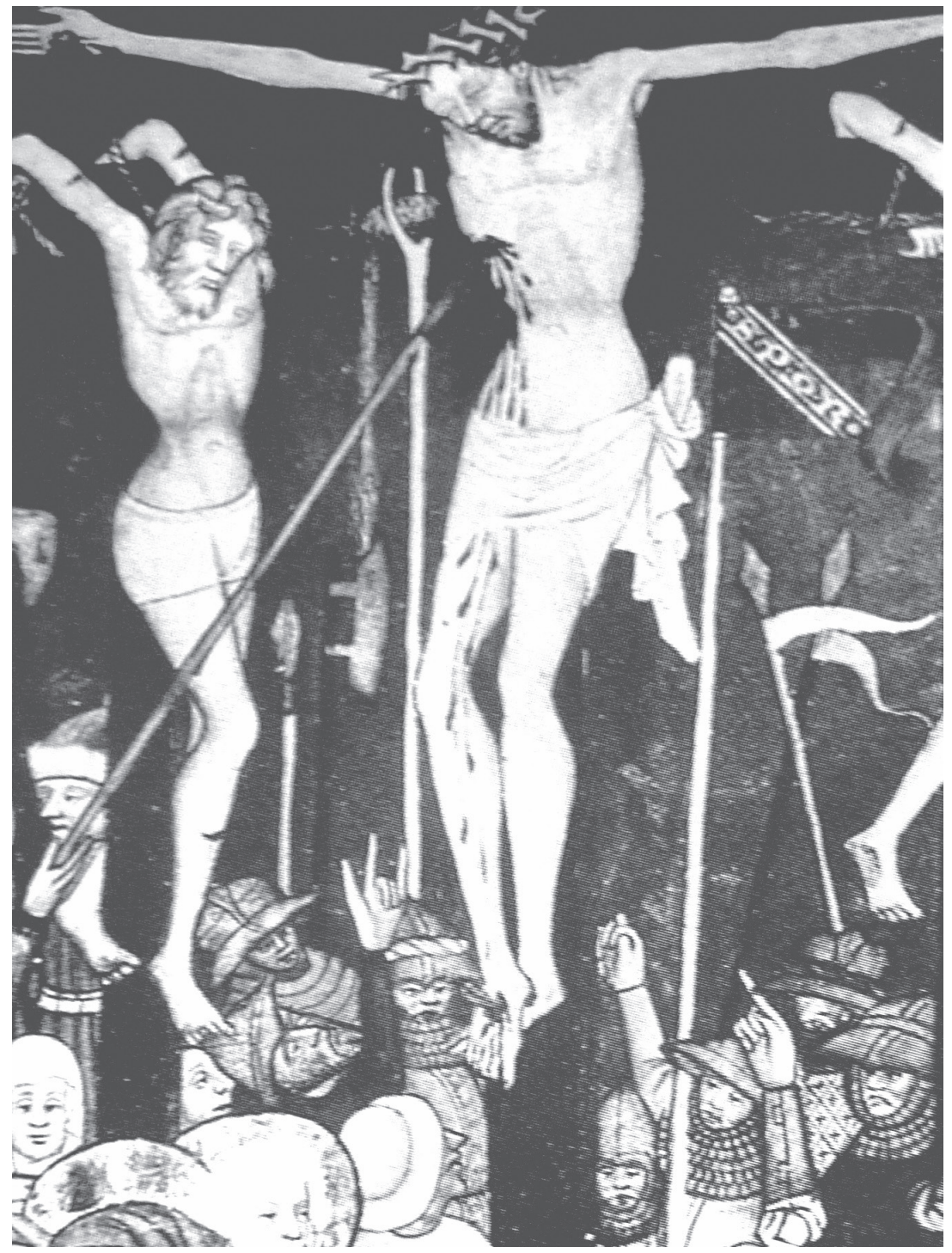

Ryc. 3. Ukrzyżowanie (frag.), Jan z Żytawy, mszał ślaski, ok 1420 r. [w:] Malarstwo gotyckie w Polsce, t. 3: Album ilustracji, red. A.S. Labuda, K. Secomska, Warszawa 2004, il. 895 


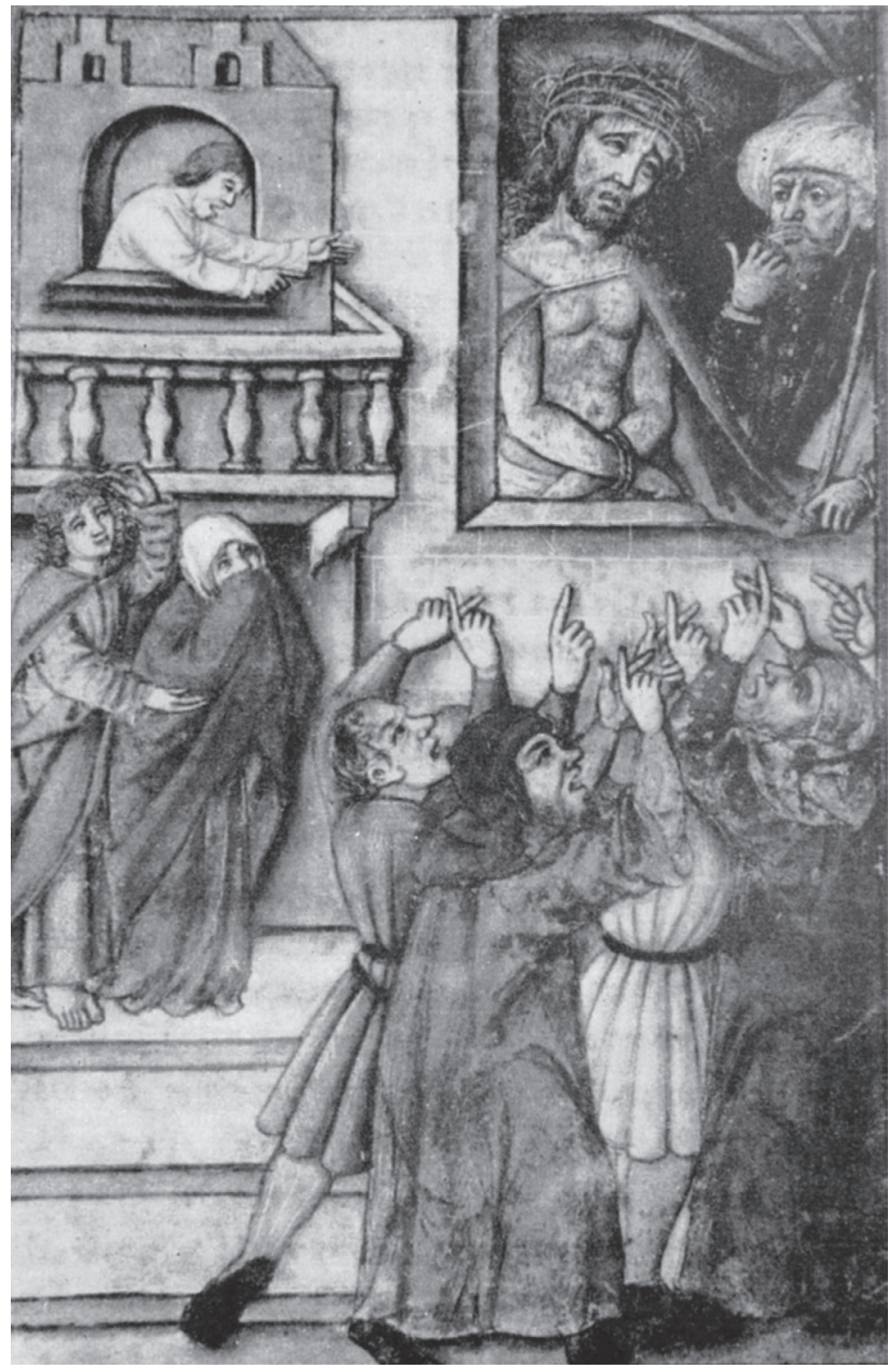

Ryc. 4. Ecce homo (frag.), Rozmyślania dominikańskie $1532 r$. [w:] Rozmyślania dominikańskie, t. 1, wyd. i oprac. K. Górski, W. Kuraszkiewicz, Z. Rozanow (oprac. ikonograficzne), Wrocław 1965, miniatura LXXXII 